\title{
Reconstruction of meandering paleo-channels using dense well data, Daqing Oil Field, Songliao Basin, China
}

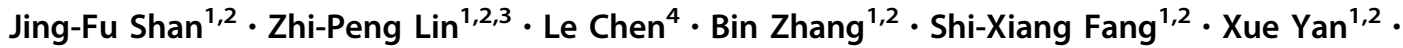 \\ Wei Fang ${ }^{1,2} \cdot \mathrm{Li}^{-\mathrm{Li} \mathrm{Xie}^{1,2}} \cdot$ Bo Liu $^{1,2} \cdot$ Le Zhang $^{1,2}$
}

Received: 22 December 2017 / Published online: 28 October 2018

(C) The Author(s) 2018

\begin{abstract}
Reconstructing meandering paleo-channels is attracting global research attention. We implemented a novel method by comprehensively integrating migration models and sedimentary structures. Firstly, the migration architectures of the corresponding characteristics in planform and cross-sectional models were summarised as expansion, translation, expansion and translation, expansion and downstream rotation, constriction and downstream rotation, and expansion and countercurrent rotation models. Secondly, full continuous core data from 270 dense drilling wells were collected from the Daqing Oil Field in the Songliao Basin, China, providing information on rock textures, sedimentary cycles, and boundary information for the two layers being studied. Through a comprehensive analysis of dense drill cores and logging data, the abandoned channels and the initial and final channel centrelines were identified. Consequently, four profiles, including one longitudinal and three transverse sections, were constructed to reveal the cross-sectional structures and planform migration architecture. Profile interpretation revealed the evolution from the initial channel centreline to the final centreline. Using a method of rational interpolation, we were able to reconstruct the migration architecture of the meandering channels. The results showed that the average ancient bankfull width $\left(W_{\mathrm{c}}\right)$ was approximately $100 \mathrm{~m}$, a single meandering belt was $800 \mathrm{~m}$, the radius of the curvature was $250 \mathrm{~m}$, the length of the channel bend was $700 \mathrm{~m}$, the average meander wavelength was $1300 \mathrm{~m}$, the sinuosity was 3.0 , and the annual average discharge rate was $450 \mathrm{~m}^{3} / \mathrm{s}$. Furthermore, we compared the results from empirical equations, which verified that our reconstruction is both feasible and potentially widely applicable.
\end{abstract}

Keywords Songliao Basin $\cdot$ Reconstruction $\cdot$ Meandering paleo-channels $\cdot$ Meandering rivers $\cdot$ Point bar ·

Planform $\cdot$ Migration architectures

\section{Introduction}

Meandering rivers are ubiquitous, dynamic earth surface systems (Seminara 2006, 2010; Abad and Garcia 2009; Güneralp and Rhoads 2011; Abad et al. 2013; Gutierrez

Edited by Jie Hao

Jing-Fu Shan

shanjingfu2003@163.com

$\bowtie$ Zhi-Peng Lin

linzhipeng@cugb.edu.cn

1 Key Laboratory of Exploration Technologies for Oil and Gas Resources, Ministry of Education, Yangtze University, Wuhan 430100, China

2 School of Geosciences, Yangtze University, Caidian, Wuhan 430100, China and Abad 2014; Lin et al. 2017). Natural channels usually flow in a meandering pattern instead of straight in alluvial plains (Hooke 2003; Engel and Rhoads 2016). The process of fluvial migration forms various river planforms (Ghinassi et al. 2016; Lin et al. 2018). River dynamics are the consequence of complex interactions between hydrology, hydrodynamics, sediment transport, bed and planform

3 State Key Laboratory of Biogeology and Environmental Geology, School of Earth Sciences and Resources, China University of Geosciences, Beijing 100083, China

4 International Publishing and Distribution Headquarter, China Academic Journal (CD) Electronic Publishing House CO., Ltd., Beijing 100083, China 
geomorphology, and other physical processes (Güneralp et al. 2012). Previous studies have characterised meandering channel migration behaviour and shape (Brice 1974; Hickin 1974; Hooke 1984; Gutierrez and Abad 2014; Schwendel et al. 2015; Lin et al. 2017) and predicted meander evolution by analytical and numerical models (Johannesson and Parker 1989; Abad and Garcia 2006; Frascati and Lanzoni 2009; Kasvi 2015; Langendoen et al. 2016). Field-based studies using terrestrial LiDAR for bank morphology can also help to interpret river bed and planform morphology (Abad et al. 2013; Konsoer et al. 2016). Surficial strata in meandering channels have been studied using ground-penetrating radar (Neal 2004; Schrott and Sass 2008; Słowik 2014, 2016). Moreover, migration patterns have been recognised and analysed in modern deposits but are seldom inferred from ancient fluvial deposits. The different planform migration modes for modern bends may be associated with soil properties (Güneralp and Rhoads 2011; Motta et al. 2012a, b), vegetation, and riverbed material (Abad and Garcia 2009; Abad et al. 2013), and bend migration patterns may be associated with floodplain- rather than channel-dominated controls (Motta et al. 2012a).

Despite the vast amount of research done in modern environments, there has been little assessment of ancient meandering channels. Research on ancient fluvial systems is limited by difficulties in recognising meandering channel migrations and transformations (Jackson 1976; Nami 1976; Leeder and Nami 1979). The paleo-morphodynamics of meandering bends have been primarily reconstructed with seismic time slices (Smith et al. 2011). Modern laboratory and field-based approaches suggest that channel bend migrations are related to hydrodynamics, sediment transport, channel adjustment, original planform shape (i.e. sinuosity), vegetation (Perucca et al. 2007), and morphological and geological constraints (Chen and Duan 2006; Smith et al. 2009; Motta et al. 2012a, b; Mendoza et al. 2016). The above factors are derived from modern environments and are difficult to link directly to ancient environments since their morphology is completely buried (Tornqvist 1993; Donselaar and Overeem 2008; Frascati and Lanzoni 2009; Cuevas Martínez et al. 2010; Ielpi and Ghinassi 2014).

Although the research methods and sedimentary environments differ between ancient and modern fluvial deposition, the evolutionary mechanisms and characteristics of river planform dynamics might follow similar hydrodynamic and sediment transport processes (Hubbard et al. 2011; Ielpi and Ghinassi 2014). It is important to characterise sand bodies of subsurface meandering belts in ancient environments to further explore for favourable hydrocarbon reservoirs. It is difficult to analyse ancient meandering dynamics based only on logging and seismic data, considering that most reservoirs are buried several thousands of metres deep. However, it can be effective when dense drilling well data are available, as in the case of the Daqing Oil Field in China. By integrating the planform distribution and cross-sectional structure of a meandering paleo-channel, this study attempted to reconstruct the evolutionary process of a paleo-channel belt.

\section{Geological background}

The Songliao Basin, with an area of $2.6 \times 10^{5} \mathrm{~km}^{2}$, is the largest and most important petroliferous basin among the 66 Mesozoic/Cainozoic basins in northeastern China (Feng et al. 2010) (Fig. 1a). The axis direction of the basin is north-easterly (Wang et al. 2007), and the area is approximately $330-370 \mathrm{~km}^{2}$ wide and $770 \mathrm{~km}$ long (Du et al. 2011). The Songliao Basin is located among a combination of discontinuous and amalgamated landmasses (Wang et al. 2013), and its tectonic evolution can be divided into four stages: mantle upwelling and doming, rifting, post-rift thermal subsidence, and structural inversion (Feng et al. 2010). Subsequently, the basin can be divided into four first-order tectonic units: the northern plunge, central depression, west slope, and southwest uplift zones (Sorokin et al. 2013). Furthermore, the basin is an important oilproducing basin in China, with 53 oil and 27 gas fields (Feng et al. 2010). Among these, the Daqing Oil Field is located in the central area of the basin (Fig. 1a).

The Songliao Basin is filled with Jurassic, Cretaceous, Paleogene, and Neogene continental clastic sediments from bottom to top, with a thickness of approximately $10 \mathrm{~km}$. The upper Cretaceous layer is mainly composed of Qingshankou $\left(\mathrm{K}_{1} q n\right)$, Yaojia $\left(\mathrm{K}_{2} y\right)$, and Nenjiang $\left(\mathrm{K}_{2} n\right)$ Formations (Fig. 1a), of which the Yaojia $\left(\mathrm{K}_{2} y\right)$ Formation developed a fluvial-delta sedimentary system. According to existing statistics (Xue 1991), reservoirs attributed to fluvial deposits occur in a high proportion of Meso-Cainozoic petroliferous basins in eastern China and are characterised by multiple sandstone-mudstone interbeds, complex heterogeneity, and lower oil recovery. The study area is located in the northern part of the central basin (Fig. 1b), and the study strata belong to the Coniacian-aged Yaojia Formation $\left(\mathrm{K}_{2} y^{1}\right)$. 


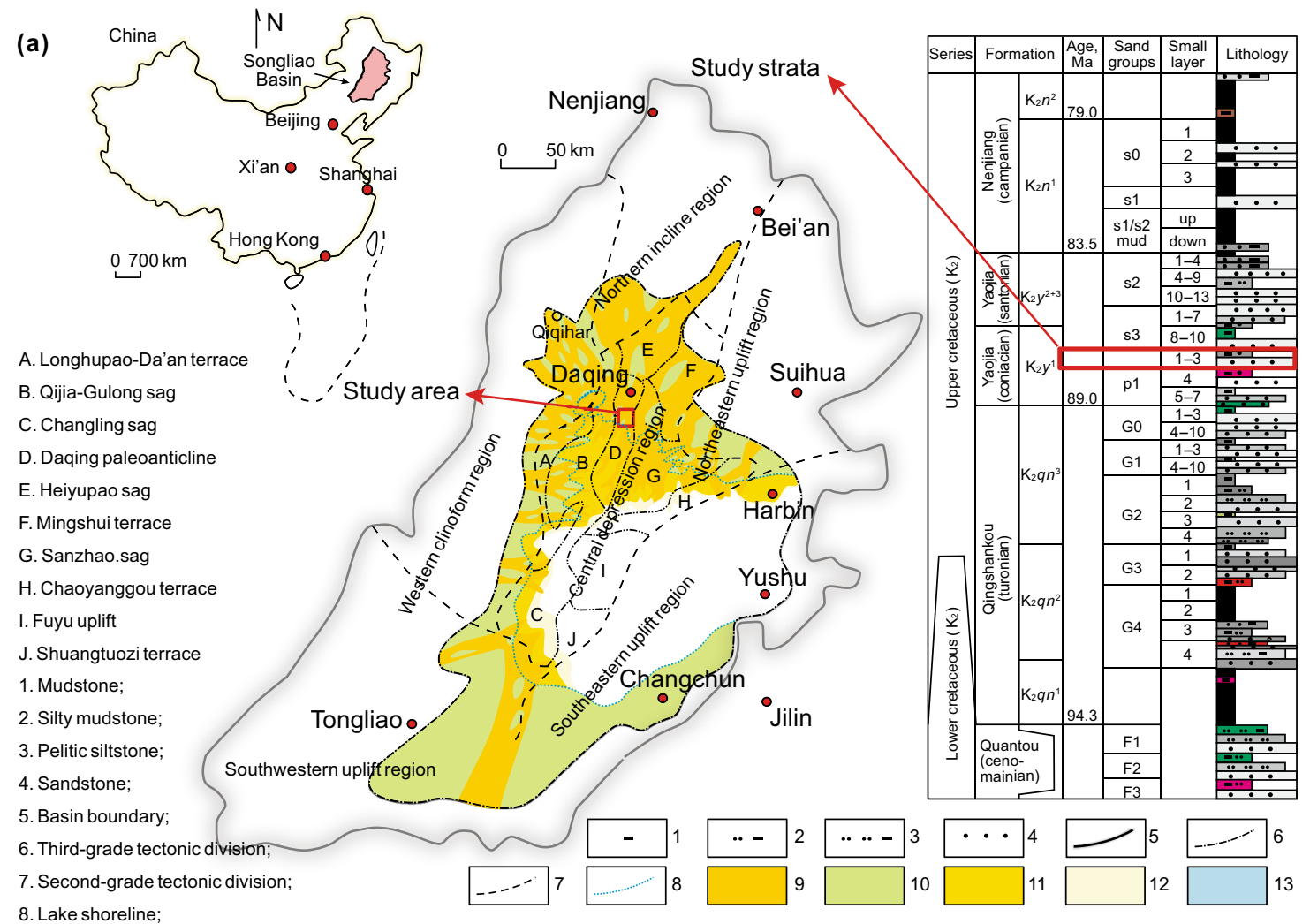

9. Channel deposits; $\quad$ 10. Alluvial plain; $\quad$ 11. Delta inner-front; $\quad$ 12. Delta extra-front; $\quad$ 13. Lacustrine deposit
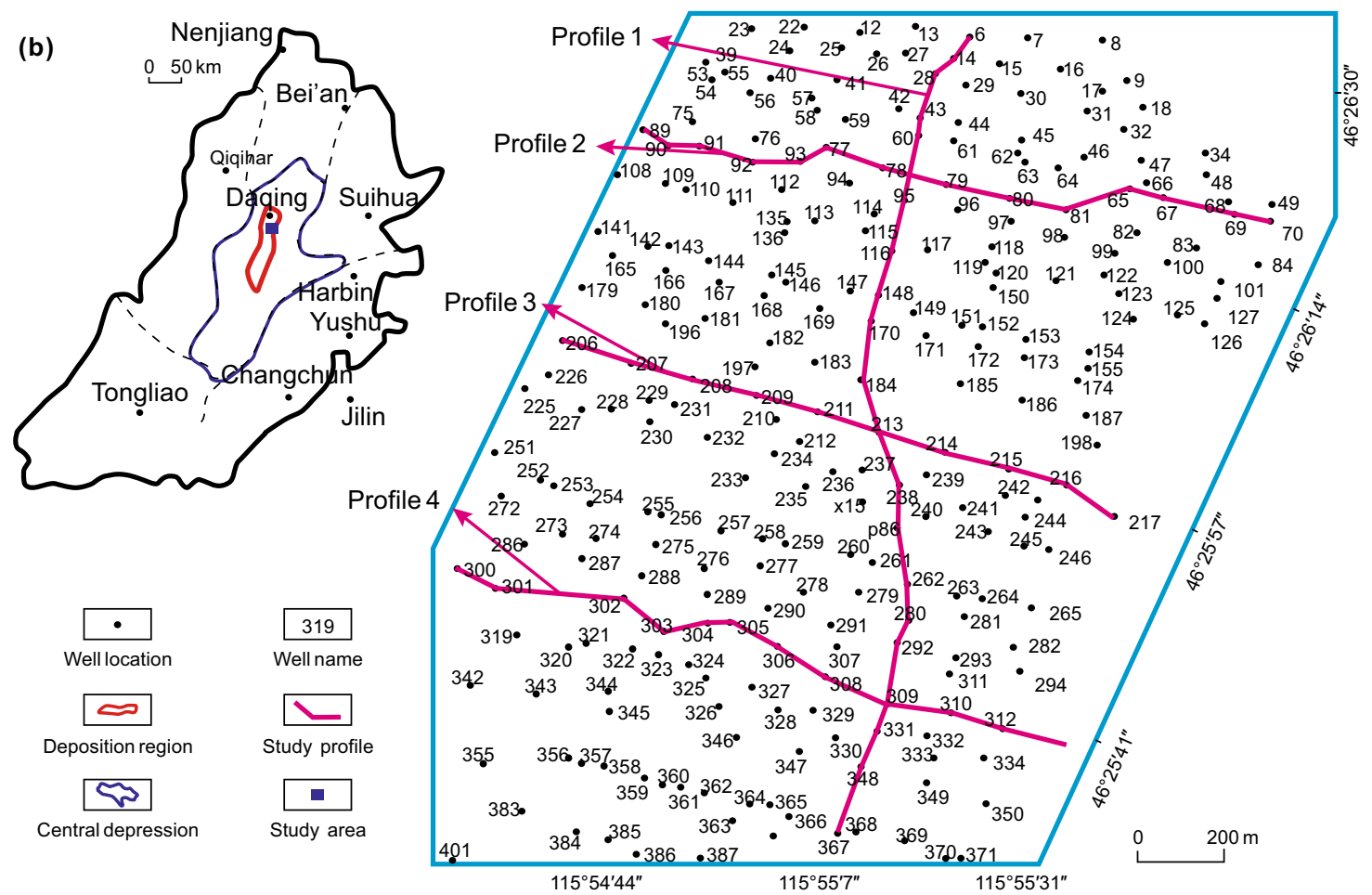

Fig. 1 a Facies, filling, and tectonic distribution of the Songliao Basin, China. b Location of dense drilling wells (270) in the central area of Songliao Basin. The azimuth of the transverse profiles is $120^{\circ}$ from west to east, and the longitudinal profile is $190^{\circ}$ from north to south. The four profiles are presented as red lines 


\section{Meandering channel architectures and migration patterns}

\subsection{Architecture hierarchy of meandering channels}

The descriptive sedimentological terminologies for meandering channel processes in this study are mainly from Harms et al. (1975), whereas the hierarchical descriptive terminologies for small-scale bedding structures are derived from Collinson et al. (1982). On this basis, the architecture of a meandering belt was recognised along the longitudinal meandering belt instead of the transverse, which is an efficient way to reconstruct the subsurface reservoir architecture (Ghinassi et al. 2014). In particular, ancient meandering channels are more difficult to identify because they are buried thousands of metres deep. Some important terminologies used in this study are explained before dissecting the sedimentary structure of the meandering belt.

The architecture hierarchy of meandering channels is characterised by both channel and overbank deposits (Wu et al. 2008; Ielpi and Ghinassi 2014; Miall 2014). The architecture hierarchy can be divided into nine scales according to the newest classification by Miall (2014) (Fig. 2a) and some architecture units need to be detailed. When a meandering river shifts from one side to the other along the alluvial plain over time, a series of meandering scrolls are formed and a single channel belt appears (Fig. 2b). As this process repeats and more channel belts gradually develop, a complex meandering belt will ultimately take shape. Different periods of a single channel belt constitute the complex meandering belt as shown in Fig. 2b. A point bar of a meandering river is a depositional unit made of alluvium that accumulates on the inner bank and is indicative of the lateral migration deposition of a river (Figs. 2, 3). Moreover, with alluvium migration and deposition at the point bar, lateral accretion bedding forms in the cross section. The point bar can also be divided into three portions: upstream, central, and downstream bars. In modern environments, these portions can be easily identified by observing flow direction and sediment deposition. However, for ancient meanders, the paleo-current flow from the upstream to the downstream bar is identified by drawing analogies to modern environments, because the volumes of downstream bar tails are convergent, whereas those of upstream bars are divergent.

Planform architecture elements of meandering channels are shown in Fig. 3 (Lin et al. 2017), which demonstrates a single meandering belt, showing the migration channels during river evolution. Based on the primary and secondary flows in a meandering channel, erosion (deposition) occurs along the concave (convex) bank (Abad and Garcia 2009; Hubbard et al. 2011; Smith et al. 2011) and is associated with a dip change from concave to convex bank orientation. The direction of internal dip parallel to the meandering loop axis is the largest and named the 'true dip', whereas the direction of internal dip is away from the meandering loop axis, which is known as the 'apparent dip' (true dip $>$ apparent dip) (Fig. 3B-B' profile). Additionally, when the internal dip sets change direction, it may indicate that the channel pattern converts into another. Furthermore, the riffle zone is located in the bend inflection where one-way transverse circulation transforms into parallel circulation (the down-cut ability of parallel circulation is weak), which usually carries sand and results in thin sand body accumulation.

\subsection{Channel migration patterns}

River migration patterns are of great significance in guiding the reconstruction of ancient channels. Migration patterns determined in this study are comparable to the results of other studies that have investigated using Google Earth maps and outcrops (Nami 1976; Ghinassi et al. 2014; Lin et al. 2018). These migration patterns include six planform migration models, which have been successfully used to reconstruct a modern fluvial system by (Shan 2017). These characteristics are observable on Google Earth (Fig. 4). Expansion increases bend curvature (by reducing the curvature radius), flow path length, and channel sinuosity, while the bend apex migrates transversely along the floodplain (Fig. 4a). Translation maintains channel sinuosity, while the bend apex migrates parallel to the channel belt axis in the downstream direction (Fig. 4b). Expansion and translation combines the expansion and translation features (Fig. 4c). Expansion and downstream rotation produces downstream-oriented bends (Fig. 4d). Constriction and downstream rotation decreases bend curvature, sinuosity, and amplitude, while the bend apex migrates downstream; this transformation is usually accompanied by the cut-off process (Fig. 4e). Finally, expansion and countercurrent rotation produces downstream-oriented bends with the final bend becoming upstream-oriented (Fig. 4f).

At this point, we considered what the corresponding relationship between the planform and cross-sectional models of meandering channels was, i.e. the corresponding characteristics between the distribution of lateral accretion bedding and channel morphology, which was also significant to the reconstruction of the paleo-channel.

Ghinassi et al. (2014) and Ielpi and Ghinassi (2014) attempted to describe the dip angle change of the lateral accretion bedding. They concluded that the angle of lateral accretion bedding of the upstream bar is greater than that of 


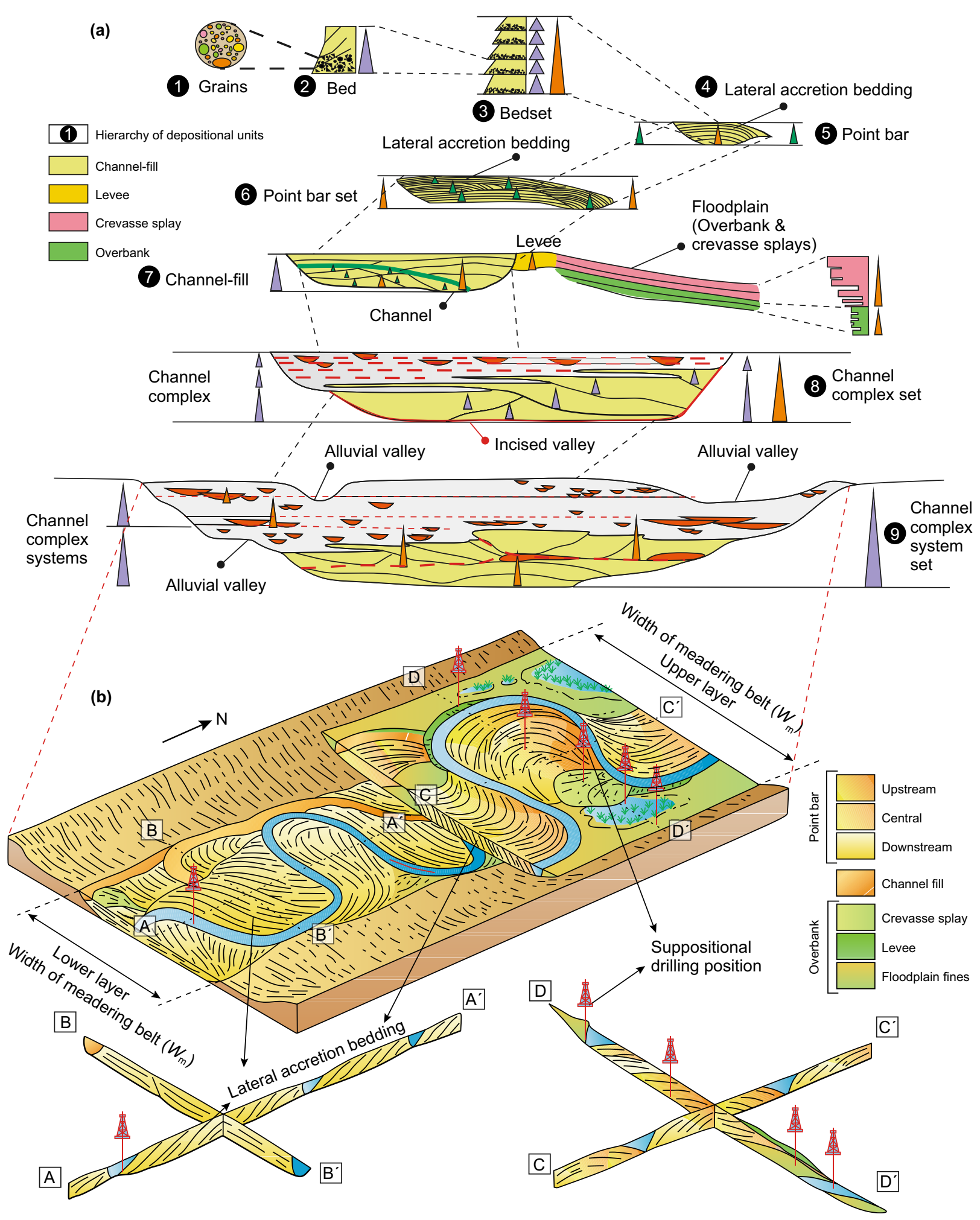

Fig. 2 Hierarchy of architectural elements of meandering channels: a hierarchy of architectural scale; b relative planform and stratigraphic signature [modified after (Ielpi and Ghinassi 2014; Miall 2014)]

the downstream bar, and it is therefore possible to relate them to hydrodynamic force differences, i.e. upstream water power is stronger than downstream water power, resulting in a deeper incision upstream and a steeper dip angle. Furthermore, different migration models demonstrate different characteristics in terms of angle changes of 


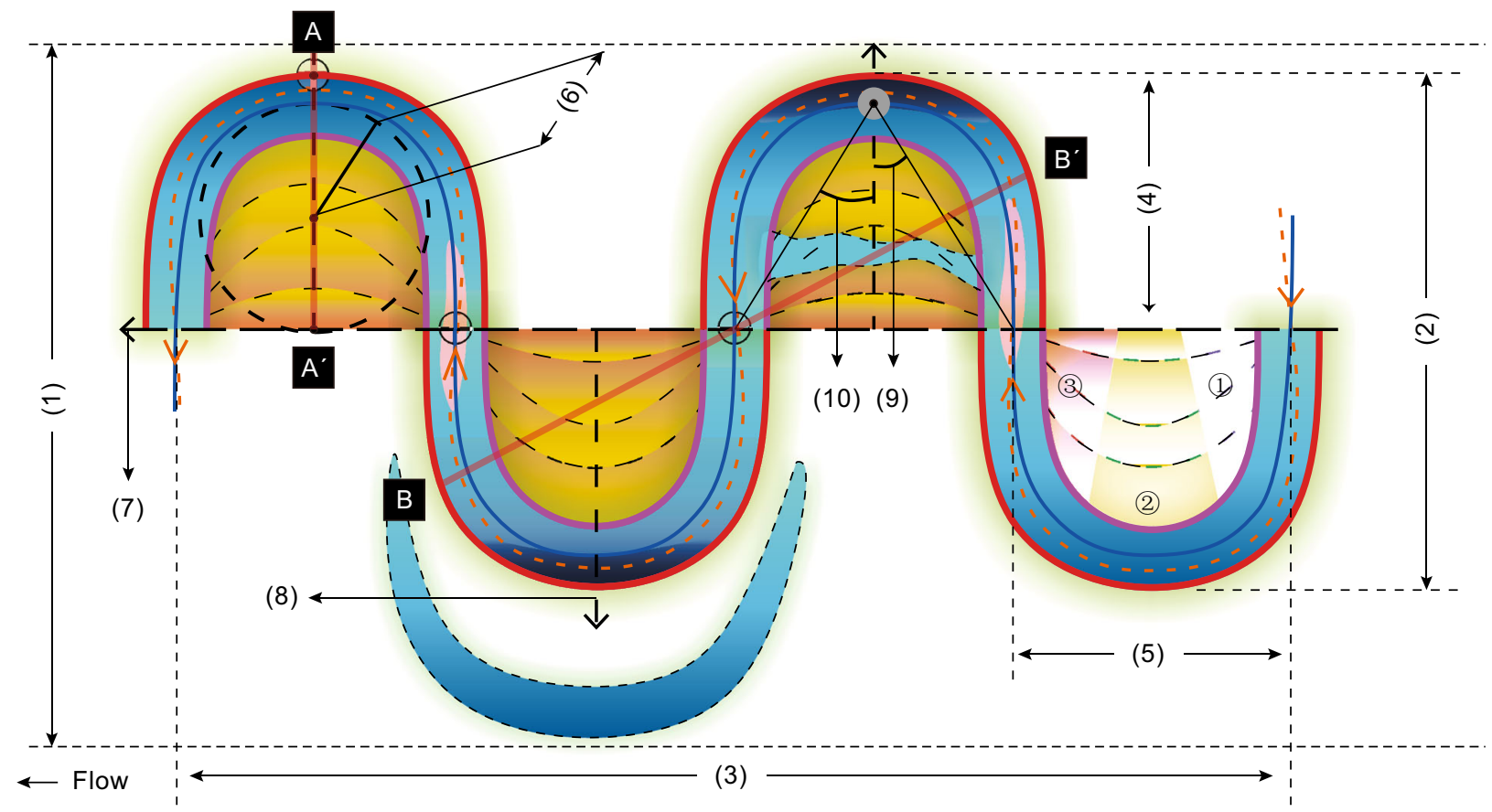

A A' B
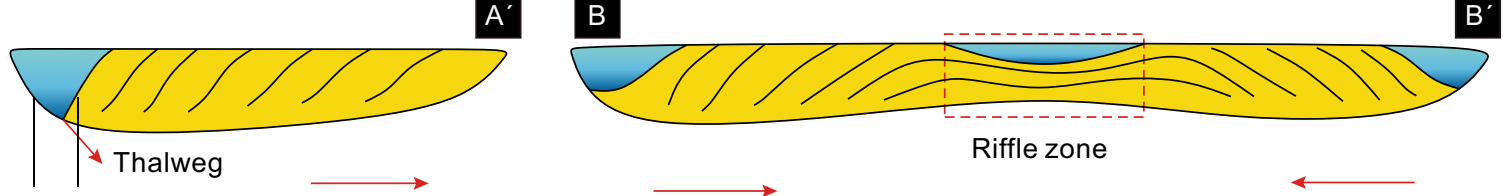

Pool zone Downtrend of interbedding dip

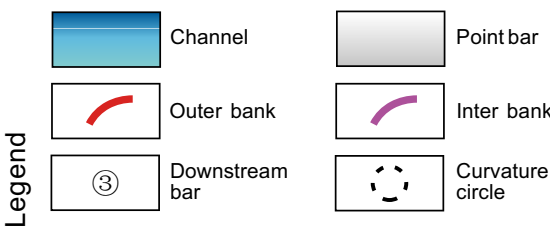

(1) Width of meandering belt, $W_{M}$

(2) Width of single meandering channel, $W_{\mathrm{SM}}$

(3) Length of single meandering channel, $L_{S M}$

(4) Width of single meandering loop, $W_{\mathrm{ML}}$

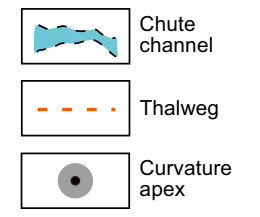

(5) Length of single meandering loop, $L_{\mathrm{ML}}$ (6) Radius of curvature, $R$

(7) Direction of meandering belt axis, $A X_{M}$ (8) Direction of meandering loop axis, $A X_{\mathrm{ML}}$

Downtrend of interbedding dip

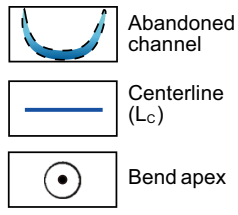

(9) Upstream deflection angle $\theta_{U}$ (10) Downstream deflection angle, $\theta_{D}$

Fig. 3 Planform architecture elements and terminology of migration architecture for meandering rivers in an ideal setting figure modified after Chen et al. (2017), and Lin et al. (2018)

the lateral accretion bedding, enabling the identification of different migration models from differences in the distribution of the lateral accumulation.

The different migration patterns are summarised as follows: (1) The expansion model (Fig. 5a) shows that the dip angle decreases parallel to the longitudinal meandering belt axis in the downstream direction $\left(\mathrm{C}-\mathrm{C}^{\prime}\right.$ profile $)$, and the inner lateral accretion bedding has an approximate symmetrical bell shape. On the transverse section, the dip angle increases as the viewpoint moves away from the meandering belt axis (D-D' profile). (2) The translation model (Fig. 5b) keeps the dip angle stable in the $\mathrm{C}-\mathrm{C}^{\prime}$ profile, while the transverse dip angle increases away from the meandering belt axis in the $\mathrm{D}-\mathrm{D}^{\prime}$ profile. (3) The expansion and translation model (Fig. 5c) is combined with the above two models in the $\mathrm{D}-\mathrm{D}^{\prime}$ profile where the transverse dip angle increases when the viewpoint is distant from the meandering belt axis, and thus the dip angles are divided into two parts, both of which decrease in the $\mathrm{C}-\mathrm{C}^{\prime}$ profile. (4) The expansion and downstream rotation model (Fig. 5d) shows the same mode of inner dip development as the expansion model $\left(\mathrm{C}-\mathrm{C}^{\prime}\right.$ and $\mathrm{D}-\mathrm{D}^{\prime}$ profiles), with a small increase away from the meandering belt axis, which is shown in the $\mathrm{D}-\mathrm{D}^{\prime}$ profile. (5) The constriction and downstream rotation model (Fig. 5e) has an inner lateral accretion bedding in an approximate symmetrical bowl shape and an initially decreasing and then increasing dip angle in the $\mathrm{C}-\mathrm{C}^{\prime}$ profile, while the dip angle decreases in 

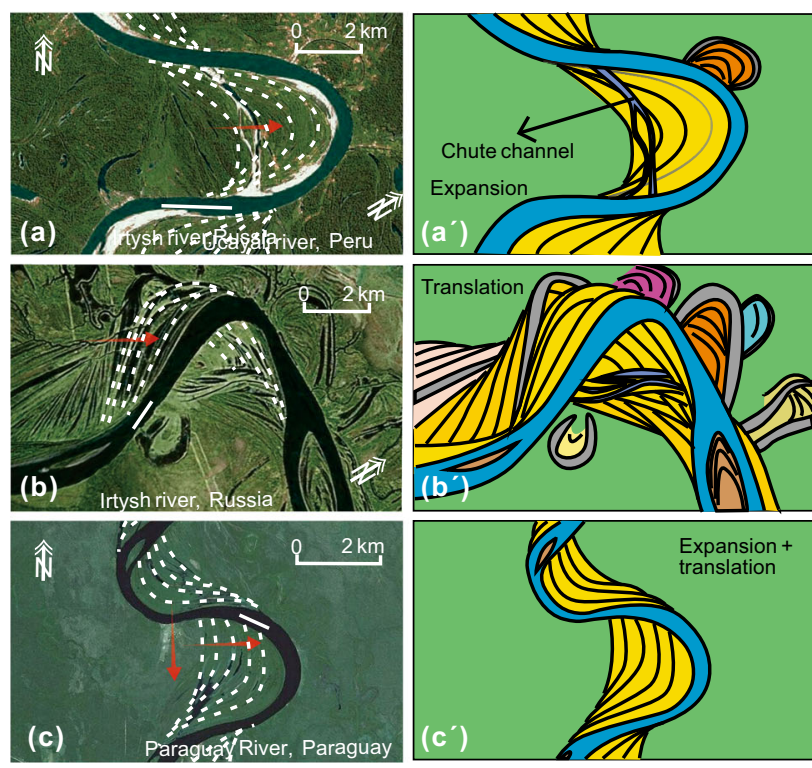

Fig. 4 Typical planform migration modes of modern rivers (left images from Google Earth; right images show the sequencing to produce complex planform migration patterns): a expansion model, Ucayali River, Peru $\left(-7^{\circ} 54^{\prime} 24^{\prime \prime} \mathrm{S},-74^{\circ} 57^{\prime} 59^{\prime \prime} \mathrm{W}\right)$; b translation model, Irtysh River, Russia $\left(59^{\circ} 32^{\prime} 24^{\prime \prime} \mathrm{N}, 69^{\circ} 03^{\prime} 00^{\prime \prime} \mathrm{E}\right)$; c expansion and translation model, Paraguay River, Paraguay $\left(-20^{\circ} 14^{\prime} 24^{\prime \prime} \mathrm{S}\right.$,

the $\mathrm{D}-\mathrm{D}^{\prime}$ profile. (6) The expansion and countercurrent rotation model (Fig. 5f) shows the dip angle decreasing and then increasing, and the angular variation is similar to the expansion model (D-D' profile). (7) The comprehensive model (Fig. $5 \mathrm{~g}$ ) has the idealised pool zone migrating from stage 1 to 4 .

The expansion and translation model plays an important role in the evolution process. The meandering bend shifted towards the downstream direction (stages $1-2$ or 3-4 in profiles $\mathrm{C}-\mathrm{C}^{\prime}$ and $\mathrm{D}-\mathrm{D}^{\prime}$, Fig. 5g) complying with the dip angle law of the profile from the translation model. In comparison, the meandering bend shifted away from the axis of the meandering belt (stages 1 or $2-3$ in profiles $\mathrm{C}-$ $\mathrm{C}^{\prime}$ and $\mathrm{D}-\mathrm{D}^{\prime}$, Fig. 5g) complying with the dip angle law of the profile from the expansion model.

The expansion and downstream rotation model is universal compared to other migration models in both modern and ancient sedimentary environments and can be identified by the migration direction of the bend apex upstream or downstream. These migration patterns are distinguished in the following manner: Using a subsurface meandering paleo-channel as an example, the bedding dip is important evidence for the inner channel. When the bend rotates upstream, a dip-paralleled profile records the transformation of the internal bedding dip angle combination (i.e. the pool migrates away from the profile upstream; stages 2-3 in profiles $\mathrm{D}-\mathrm{D}^{\prime}$ or $\mathrm{C}-\mathrm{C}^{\prime}$, Fig. $5 \mathrm{~g}$ ). In contrast, in downstream rotation, a dip-paralleled profile records an initial
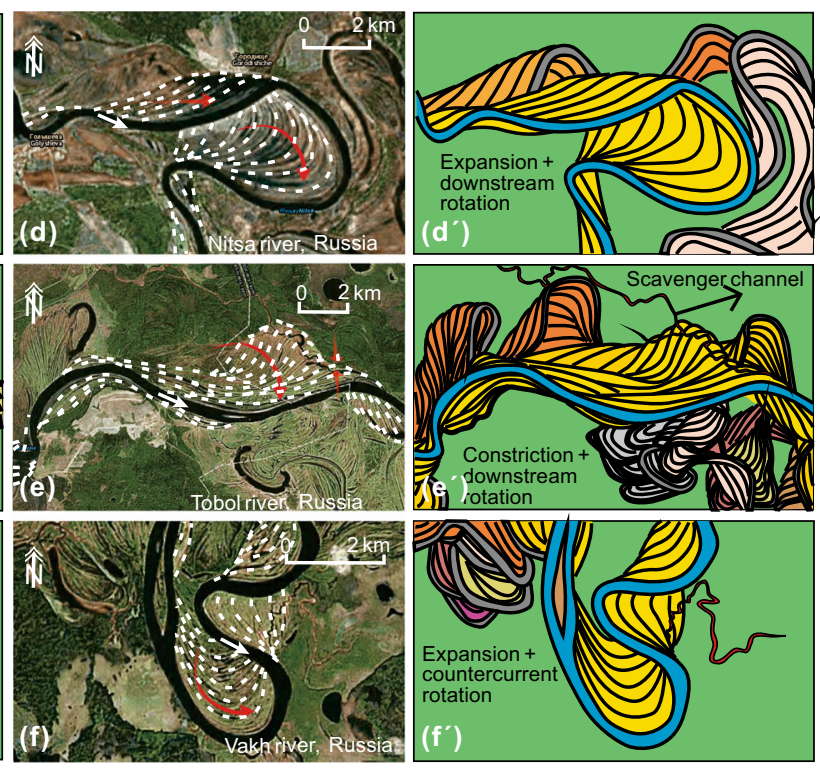

$\left.-58^{\circ} 06^{\prime} 00^{\prime \prime} \mathrm{W}\right)$; d expansion and downstream rotation model, Nisa River, Russia $\left(57^{\circ} 27^{\prime} 00^{\prime \prime} \mathrm{N}, 64^{\circ} 43^{\prime} 12^{\prime \prime} \mathrm{E}\right)$; e constriction and downstream rotation model, Tobol River, Russia $\left(57^{\circ} 51^{\prime} 00^{\prime \prime} \mathrm{N}\right.$, $\left.67^{\circ} 33^{\prime} 36^{\prime \prime} \mathrm{E}\right)$; f expansion and countercurrent rotation model, Vakh River, Russia $\left(61^{\circ} 03^{\prime} 00^{\prime \prime} \mathrm{N}, 77^{\circ} 49^{\prime} 12^{\prime \prime} \mathrm{E}\right)$

decrease in the internal bedding dip, followed by an abrupt increase (e.g. stages $1-2$ in profiles $\mathrm{D}-\mathrm{D}^{\prime}$ or $\mathrm{C}-\mathrm{C}^{\prime}$, Fig. $5 \mathrm{~g}$ ). Upstream or downstream migration leads to different dip patterns, and these rotations are generally associated with changing hydrodynamics, e.g. alternating flood and drought seasons. In addition, rotational mechanisms are associated with increasing bed dips (Ielpi and Ghinassi 2014). Unstable angles are an important trigger factor, and high flood stages improve the probability of pool migration. In fact, inconsistent variation in dip angles indicates the rotation of point bars. Although the response characteristics are obvious in an outcrop section, it is not yet possible to accurately identify the distribution of lateral accretion bedding under the limited conditions of subsurface viewpoints, and this needs further research.

\section{Database and methodology}

The data sets used in this study comprised dense well data from the Daqing Oil Field in the Songliao Basin, China, which includes full continuous core data and considerable well-logging data from 270 dense drilling wells. The well spacing is $80-150 \mathrm{~m}$. Based on the comprehensive interpretation of well and core data, the complex meandering belts were reconstructed with a combination of migration patterns of the meandering paleo-channels, which can only be observed in dense wells. 
(a)
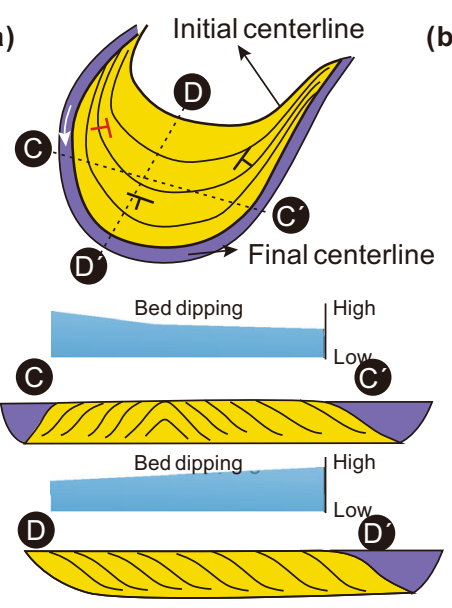

Expansion

(d)
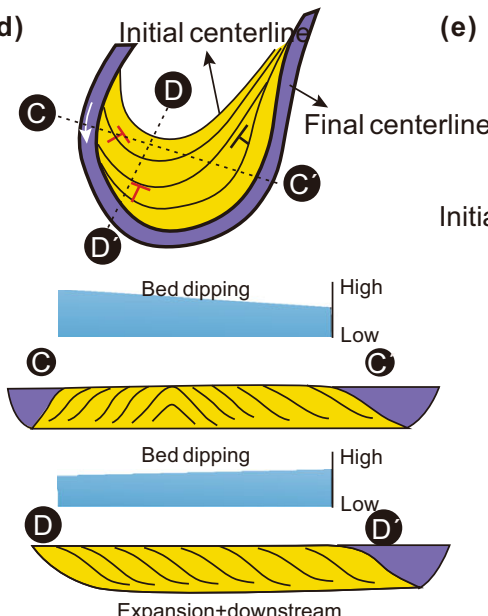

Expansion
rotation

(e) (b)

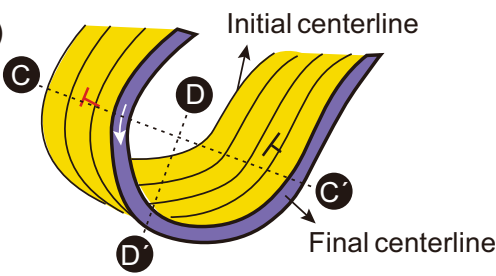

(c)

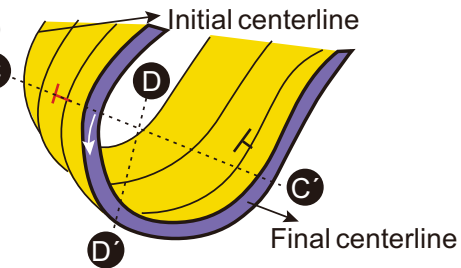

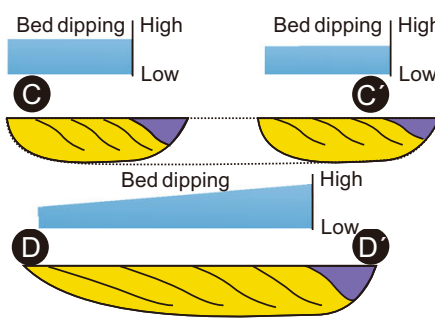

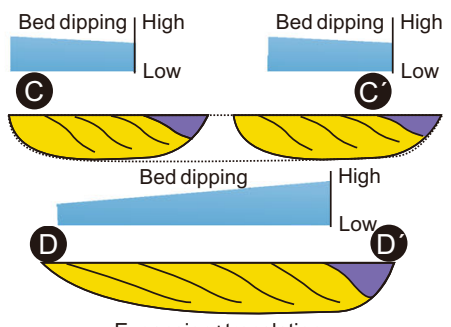

Expansion+translation

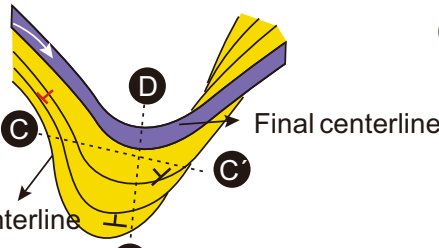

(f)

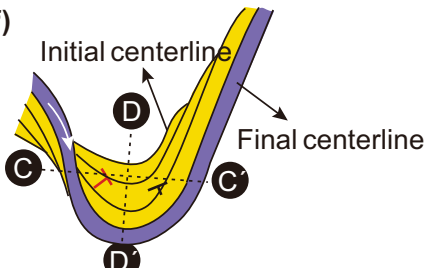

D
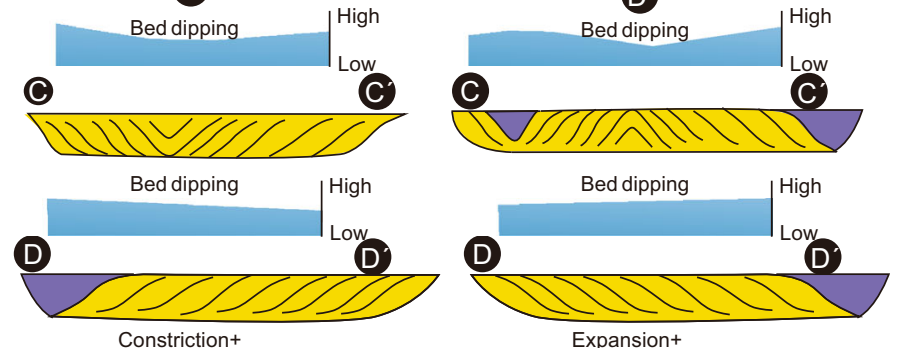

downstream rotation

countercurrent rotation
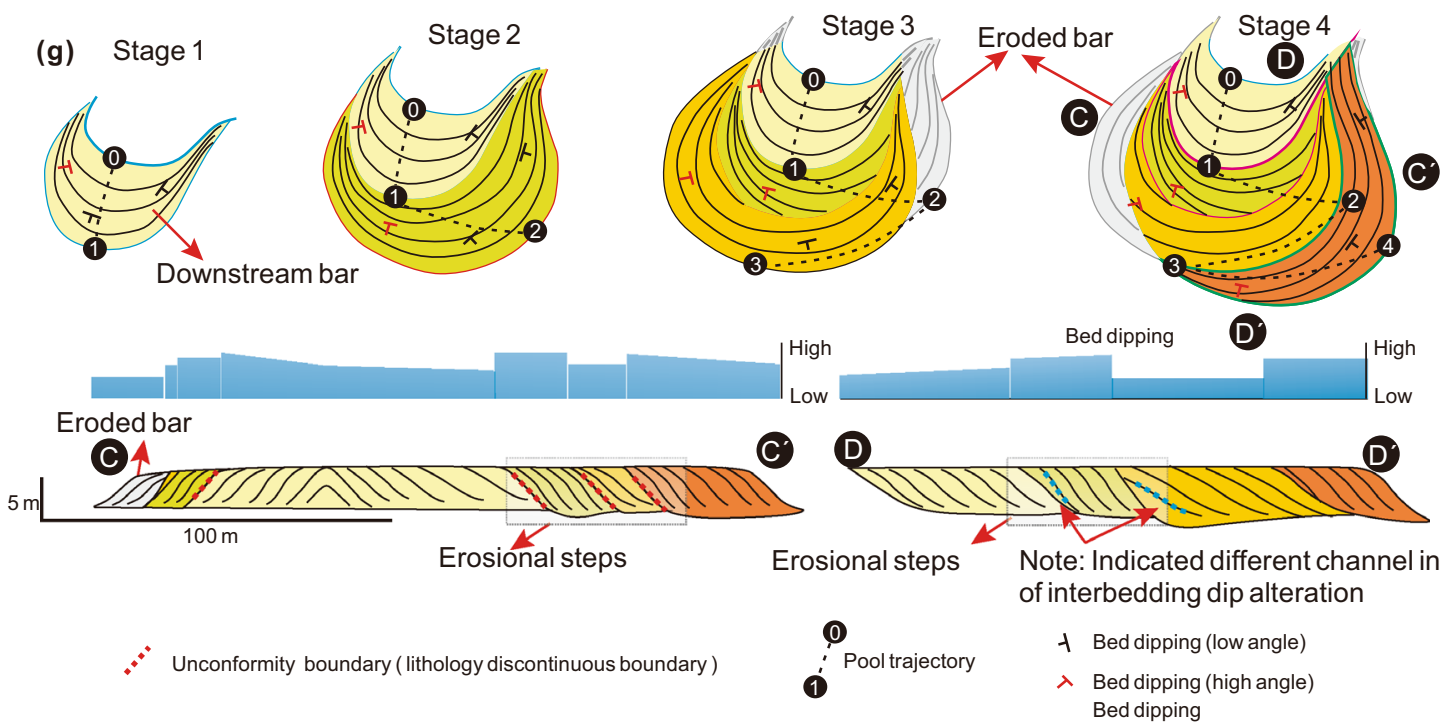

Fig. 5 Corresponding relationship between the planform and cross-sectional models of migration patterns. a-f Similar to that in Fig. 4; $\mathbf{g}$ stages (1-4) of pool zone migration modified after Ielpi and Ghinassi (2014) 

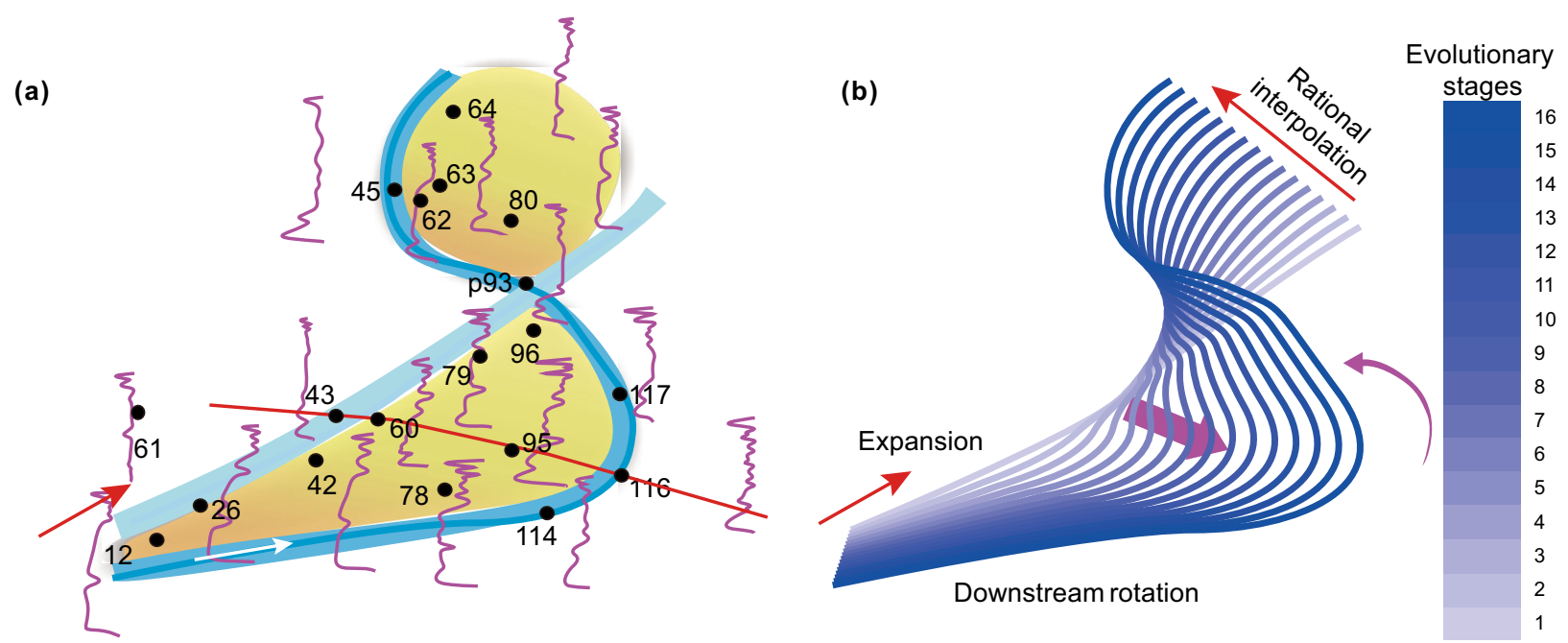

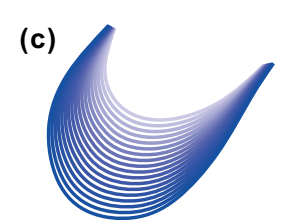

Expansion

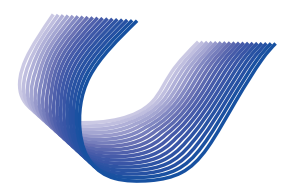

Translation

Expansion \& downstream rotation model

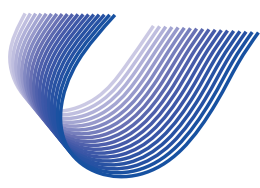

Expansion \& translation

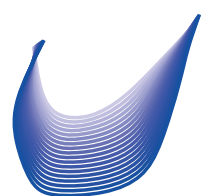

Expansion \& downstream rotation

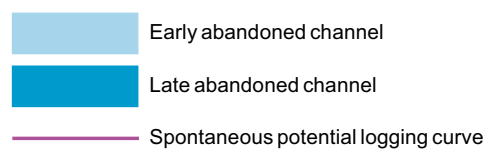

Fig. 6 Identification method of the migration models of paleomeandering channels: a identification of abandoned channels taking bend b (Fig. 7c-B) as an example; $\mathbf{b}$ establishment of the initial and

With this full coverage of multiple wells, four key profiles are illustrated, and core data were collected for each profile. By integrating the core structure, lithological successions, small layer correlations, and scouring surfaces with those of previous studies, each of these profiles was interpreted and identified as the various stages of a meandering belt.

Here, we take Profile 1, belt $\mathrm{b}$ as an example to briefly introduce the research ideas (Fig. 6). The reconstruction of the meandering paleo-channel can be summarised as follows: firstly, by using comprehensive analyses of dense well cores and logging data, the abandoned channels were identified, as shown in Fig. 6a. The lateral accretion bedding was revealed by core and log data analyses, which could further be used to identify the early and late abandoned channels. Furthermore, the abandoned direction of the river indicated the migration direction, and the initial and final channel centrelines could subsequently be inferred in plan view (Fig. 6b). Due to the distance between the wells and the underground conditions, the sedimentary final centrelines and the rational interpolation of evolutionary processes; $\mathbf{c}$ identification of different channel bends and migration patterns

process between the initial and final centrelines could not be identified. The evolution from the initial to the final centreline could thus be speculated by the rational interpolation method (Ruiu et al. 2016). As shown in Fig. 6a, a total of 16 evolutionary stages of channel centrelines were reconstructed.

Moreover, the limited well spacing conditions were used to reveal the distribution characteristics of the lateral accretion bedding. Combined with the changes of lateral accretion bedding and their corresponding relationship to the planform structure as shown in Fig. 5, different migration modes were identified in each section as shown in Fig. 6c. After recognising the migration modes in each profile, the migration architecture of the entire study area was determined, and, on this basis, the evolution and reconstruction of the course of the meandering paleo-river could be completed. 
Table 1 Lithology and stratification code symbols, modified after Miall (1977, 1985), and Waksmundzka (2010, 2012)

\begin{tabular}{llll}
\hline Lithology code & Textural feature & Stratification code & Structural feature \\
\hline G & Conglomerate & $\mathrm{m}$ & Massive structure \\
GS & Sandy conglomerate & h & Horizontal lamination (stratification) \\
S & Sandstone & f & Flaser lamination \\
SG & Gravelly sandstone & w & Wavy lamination \\
SF & Silty sandstone & n & Lenticular lamination \\
FS & Sandy siltstone & r & Ripple cross-lamination \\
F & Mudstone/claystone & 1 & Low-angle cross-stratification \\
R & Claystone/sandstone & p & Planar cross-stratification (tabular and wedge-shaped) \\
I & I & t & Trough cross-stratification \\
I & I & x & Large-scale cross-stratification \\
I & I & s & Scour-fill, massive or cross-stratified sandstone/conglomerate \\
& & & with clasts on an erosional surface \\
\hline
\end{tabular}

\section{Sedimentary elements of meandering channels}

Although the application of the above conceptual model has been reported in previous literature (Bridge et al. 2000; Ghinassi et al. 2013), this method was applied to the Daqing Oil Field, where extensive well data were available, thus enabling detailed sedimentological characterisation of the ancient planform migration modes. This study presents the relationships between lithofacies and environmental elements. All lithofacies were coded (Table 1) following the descriptions by Miall (1977, 1985), and Waksmundzka (2010, 2012).

\subsection{Lithological facies codes}

The large scale of cross-stratified sets was difficult to interpret due to limited viewpoints provided by core and lithological data. For example, it was impossible to distinguish between planar cross-stratification (Sp) and trough cross-stratification (St), and thus large-scale stratification had an objective existence. These bedding were coded using ' $x$ ' (e.g. Sx). However, this study emphasised architecture elements of point bars rather than stratification dimensions. These associations probably contain Sp based on sedimentary environment analysis. In contrast, the study of scouring boundaries in channel bottoms is more important in identifying the different evolutionary stages of rivers. The original lithofacies were combined, reclassified, and coded following descriptions by Miall (1977), Waksmundzka (2010), and Ielpi and Ghinassi (2014), as shown in Table 2.

\subsection{Identification of key architectural elements}

The complex meandering belt structure of the subsurface network of well data was characterised by both inner channels and overbank deposits, whose architectural elements were mainly composed of point bars and channel fills. The classification developed for this study (using interpretation from multiple drilling holes) agreed with that of previous studies (e.g. Feng et al. 2010).

Table 2 Lithofacies code symbols and recognised architectural elements, modified after Miall (1977), Waksmundzka (2010), and Ielpi and Ghinassi (2014)

\begin{tabular}{|c|c|c|c|}
\hline Environment & Sedimentary element & Lithofacies & Shape \\
\hline \multirow[t]{3}{*}{ Channel } & Point bar & $\begin{array}{l}\text { Sr, Sp, St, Sx, Sl, Sh, } \\
\text { Sm, SGm, Gp, Gt }\end{array}$ & $\begin{array}{l}\text { Convex, crescent-shaped with curved, centrifugal bedding; strongly } \\
\text { asymmetrical or missing the upstream portion in places }\end{array}$ \\
\hline & Channel fill & Gs, GSs, Ss, SGs & Irregular, concave erosional-based lithosome \\
\hline & Channel pool & St & Very large-scale St \\
\hline \multirow[t]{3}{*}{ Overbank } & Crevasse complex & SFr, SFw, FSr, FSw, FSn & $\begin{array}{l}\text { Convex, sub-circular mounded lithosome, in places erosionally topped by } \\
\text { minor channel fills }\end{array}$ \\
\hline & Levee & SFr, FSh, FSf, FSw & Wedge thinning channel \\
\hline & $\begin{array}{l}\text { Floodplain fine- } \\
\text { grained deposition }\end{array}$ & $\mathrm{Fm}, \mathrm{Fh}$ & Tabular lithosomes with minor top ridges and swales \\
\hline
\end{tabular}


Inner channel elements composed of point bars (derived from all kinds of migration modes of meandering bends) and channel fills accounted for almost $48 \%$ of planform exposure after meandering channel sedimentation in the Yaojia Formation. Furthermore, the lithology of the inner channel was relatively coarser and better preserved in the riverbed than in the overbank deposits. The overbank elements included a crevasse system, channel-levee, and finegrained floodplain fills. These elements accounted for approximately $52 \%$ of the planform exposure, and therefore the preservation potential of overbank sediments was limited due to reworking by rechannelling, cut-off, and neighbouring channels. Thus, overbank elements were relatively poorly preserved, whereas upper-layer overbanks were better preserved.

\section{Reconstruction of meandering paleo- channels}

\subsection{Profile interpretations}

Profile 1: this profile (Fig. 7) extends from the north to south of the study area (parallel to the axis of the longitudinal meandering belt or valley). Flow direction and erosional boundaries were obtained based on data from well $\operatorname{logs}$ and cores. Because the pre-meandering belt suffered from powerful reworking, the earlier point bar of Layer 1 was incompletely revealed, making it difficult to reconstruct. In addition, most exposures were late-stage meandering belts at the end of the fluvial deposition period in the Yaojia Formation. Therefore, the interpretation of the meandering belt in this study focused on Layer 2 (see Fig. 7b). Bends (A) (wells 6-28) and (B) (wells 43-116) showed erosive boundaries that suggest the interface of two channels with traction flow mechanisms. Based on observations in drill cores and interpretation of adjacent well data (Fig. 7a), the initial and final channel centrelines are sketched in Fig. 7c and show the process of centreline migration by rational interpolation (Fig. 7c-A-F). Bend (A) migrated from left to right and rotated upstream (Fig. 5c-A), whereas bend (B) migrated from left to right but rotated downstream (Fig. 7c-C). The results indicate that bend (A) migrated upstream with expansion, while the apex (pool zone) migrated transversely away from the channel belt axis and developed an asymmetric shape. The late-stage channel superposed on an earlier channel in well 60 , indicating that channels of two stages were penetrated. Bend (B) partially reworked the downstream bend (A).

Bends (C) and (D) are from wells 170-262 on the profile. Numerous wells revealed the scouring surfaces, and the channel centreline distribution mode is shown in Fig. 7c-C. The migration of bend (C) was downwards, whereas that of bend (D) was in the opposite direction (Fig. 7c-D). The results indicate that bend (C) migrated with the expansion and rotation mode, deviating away from the meandering belt axis, whereas bend (D) migrated with the same mode but in the opposite direction. Paralleling the longitudinal meandering belt axis, the segment bend size was smaller relative to other bends. Furthermore, according to data from well 213, bend (D) superposed onto bend (C).

Bend (E) is from wells 292-367 on the profile. The segment parallels the longitudinal meandering belt axis, combining adjacent wells and core observation results, the scouring surfaces were revealed due to an earlier channel being eroded by a later one. The initial and final channel centrelines are shown in Fig. 7c-E. The migration of bend (E) was upwards with multi-looped expansion deviating away from the meandering belt axis and becoming more complicated over time.

Profile 2: this profile (Fig. 8) extends in a west-east direction transversely across the meandering belt. Bend (A) was characterised by a single meandering belt with relatively large curvature, whereas bend (B) showed a highly tortuous segment superposing upon the earlier bend (A) (Fig. 8). Furthermore, bend (A) migrated with the expansion mode, deviating from the meandering belt axis, whereas bend (B) migrated by the expansion and rotation mode, paralleling the meandering belt axis.

Bends (C) and (D) were from wells $78-70$ on the profile. This profile shows meandering channels from two periods that were superposed on each other (Fig. 8). Bend (C) was characterised by high curvature, whereas bend (D) was characterised by a relatively low curvature and onlaps. Furthermore, bend (C) migrated with the translation and expansion mode, deviating from the meandering belt axis downstream.

Profile 3: this profile (Fig. 9) extends from west to east transversely across the meandering belt. Meandering channels from two stages are superposed on each other in Fig. 9. Bend (A) was characterised by a relatively low curvature, whereas bend (B) showed a highly tortuous bend, which was prone to cut-off. The initial channel centreline of bend (A) was completely eroded whereas bend (B) migrated with the expansion and rotation mode, paralleling the meandering belt axis (Fig. 9).

Bends (C) and (D) were from wells 213-216. Two-stage meandering channels with cut-off structures (i.e. light blue line representing original channel centreline and blue line representing the final channel centreline) were interpreted and supported by abundant core data (Fig. 9). Bend (C) was characterised by low curvature accompanying a cut-off in the earlier stage of growth. The cut-off was adjacent to bend (C), which developed before forming a residual point bar, whereas bend (D) was characterised by chute channel formation. This chute segment was inferred 
(a)
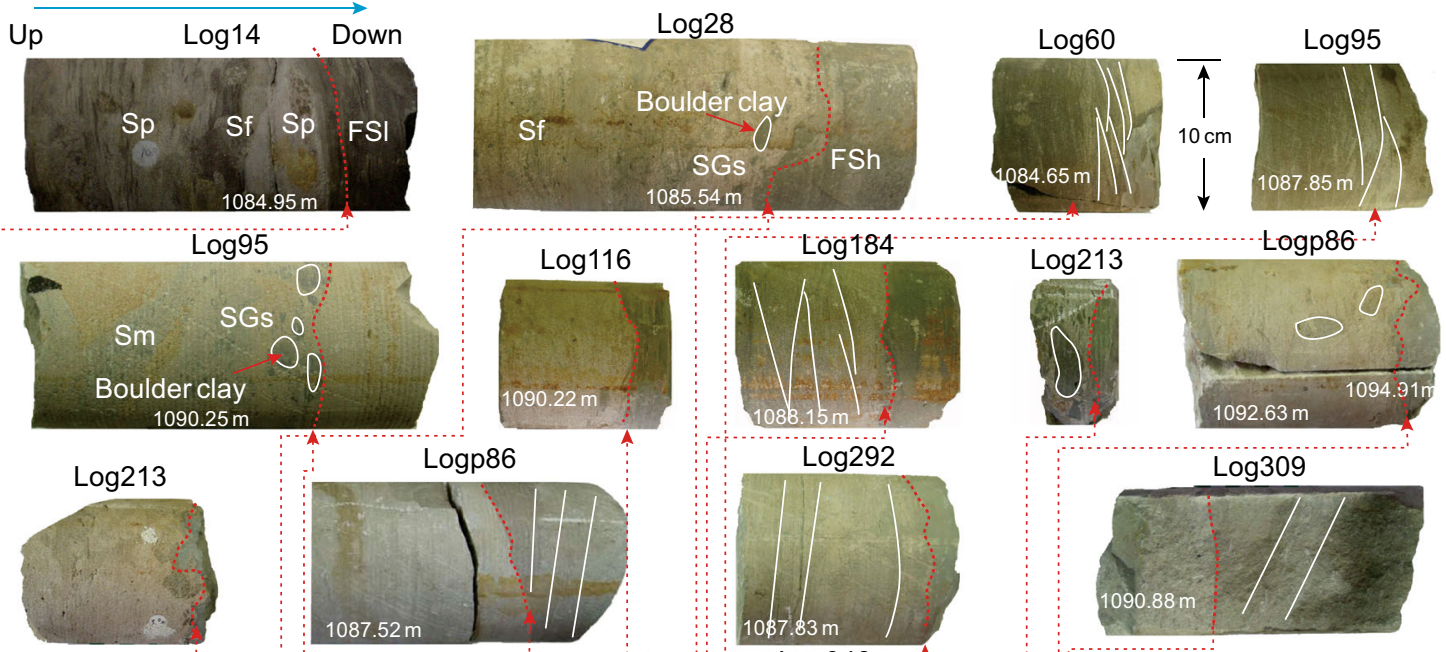

Logp86
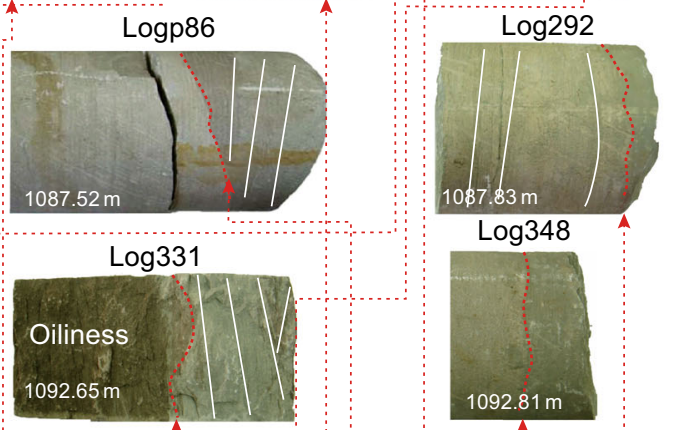

$\log 309$
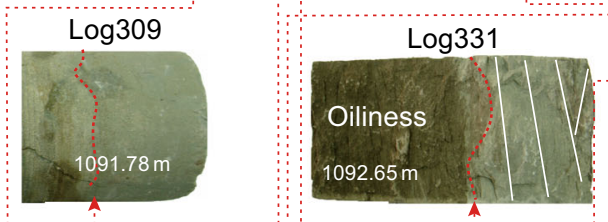

A
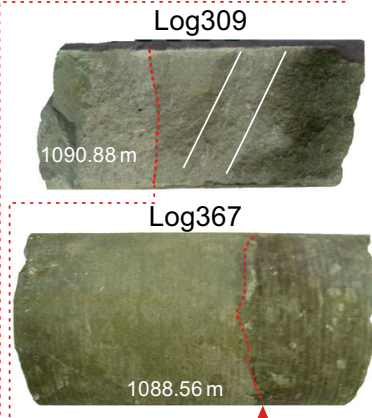

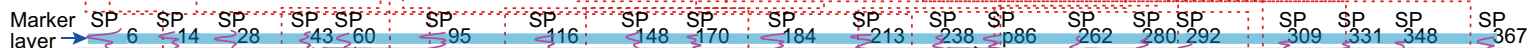

(b)

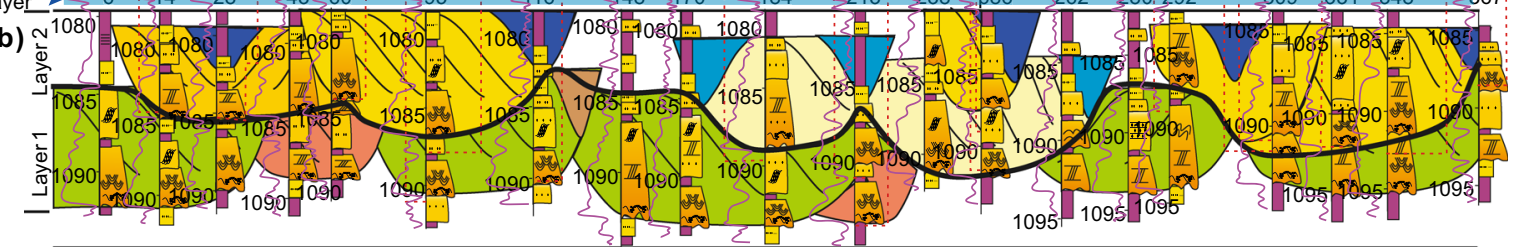

(c)

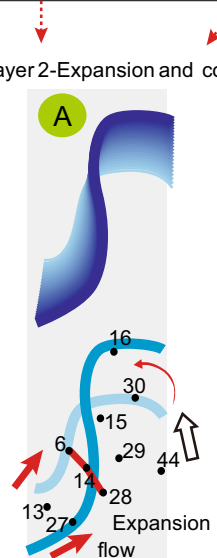

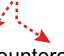

ercurrent rotation
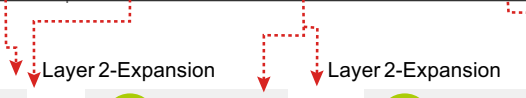

Layer 2-Expansion with multi-loop
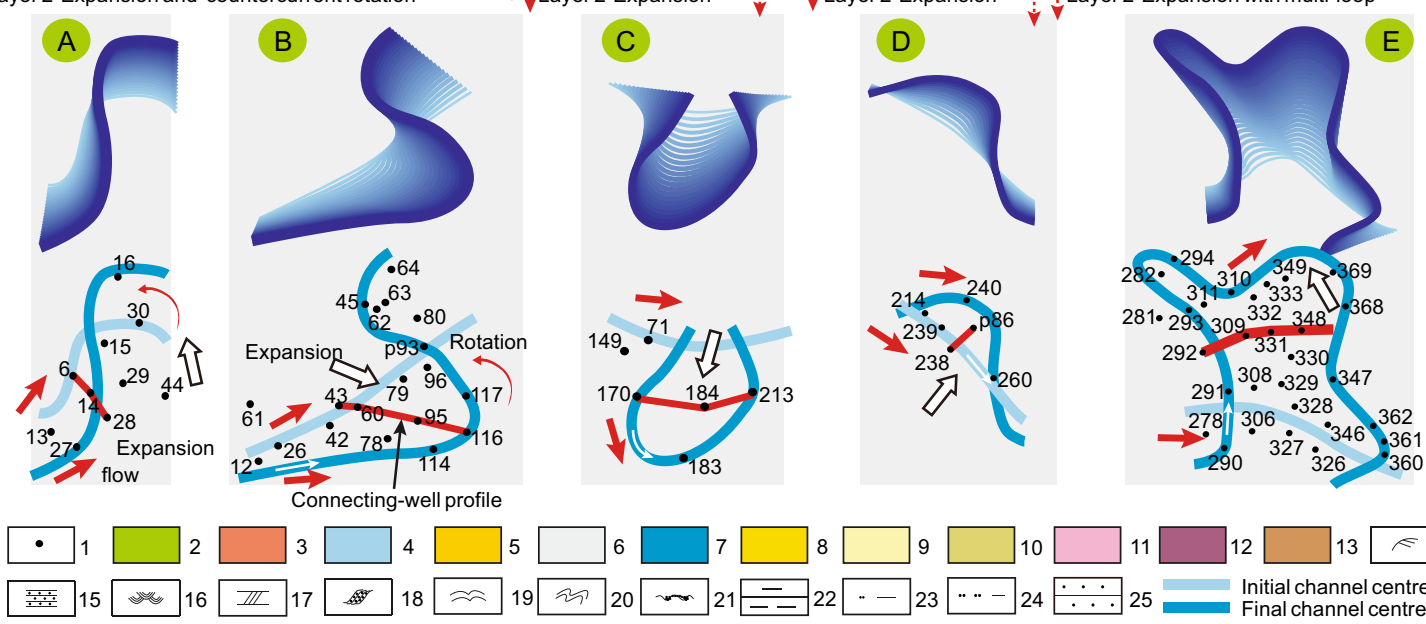

1. Well boreholes;

2. Layer 1 meander belt;
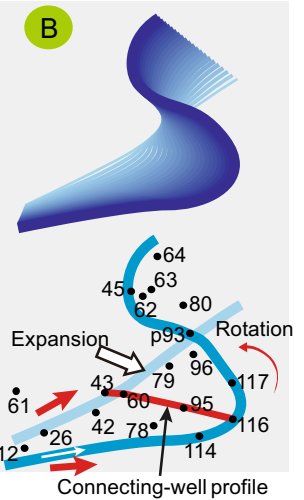
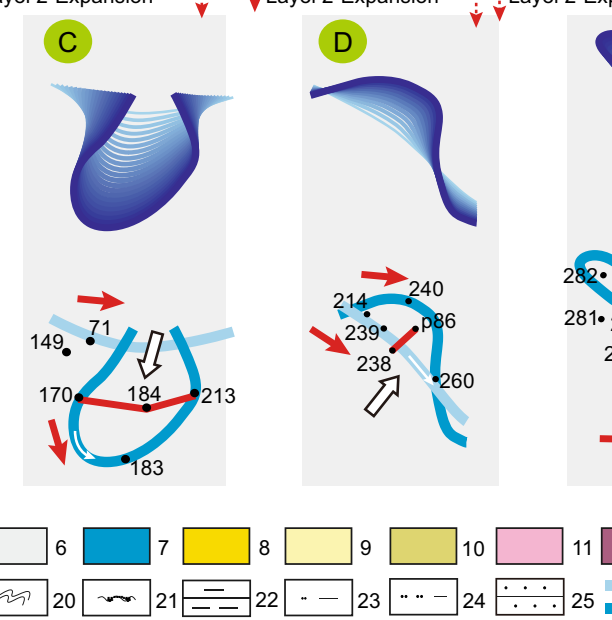

$8 \approx 19 \approx 20 \approx 21=22$

8. Layer 2-middle meandering channel;

9. Layer 2 cutoff point bar for middle channel;

10. Layer 2-right meandering channel;

11. Layer 2 cutoff point bar for right channel;

12. Layer 1 chute channel;

13. Layer 1 abandoned channel;

14. Ripple cross lamination;

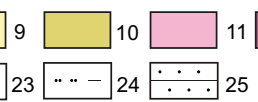

15. Parallel bedding;

16. Trough cross-bedding;

17. Tabular cross-bedding;

18. Lateral accretion bedding;

19. Wavy bedding;

20. Deformed bedding

21. Erosion surface;
Fig. 7 Profile 1: longitudinal profile parallel to the meandering belt axis (from north to south) in the Daqing Oil Field in the central area of the Songliao Basin: a core data, b lithological interpretation, and c planform interpretation (vertical scale is exaggerated for the purpose of visualisation) 


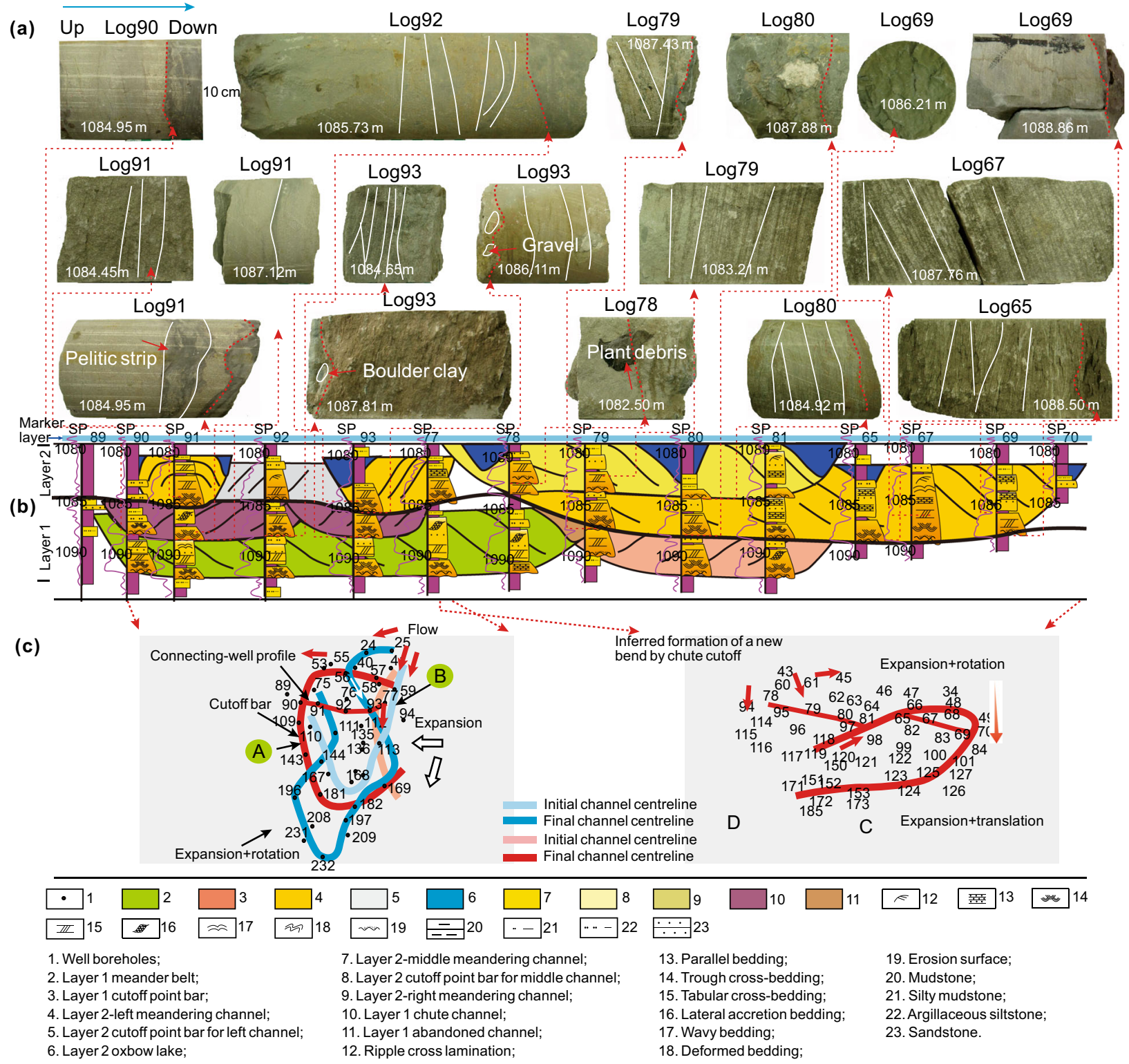

Fig. 8 Profile 2: profile map of comprehensive analysis including the evolution model of the meandering belt, based on multiple-well data collected from the Daqing Oil Field. Profile parallels the transverse

from an inflection in bend (C), which migrated with the translation and expansion mode, deviating from the meandering belt axis downstream. Conversely, bend (D) was characterised by an exceedingly low curvature, indicating a lower tortuous meander evolution process, and migrated with the expansion mode, deviating away from the meandering belt axis downstream (Fig. 9).

Profile 4: this profile segment (Fig. 10) extends from wells 302-312. Two-stage meandering channels appending a chute channel (light green line representing initial channel centreline and green line representing the final channel centreline) were interpreted with multi-stage superpositions and supported by the core data (Fig. 10). axis of the meandering belt, with exaggerated vertical scale: a core data, b lithological interpretation, and $\mathbf{c}$ planform interpretation

Bend (a) was characterised by medium curvature accompanying a cut-off at the earlier growth stage (Fig. 10c-A). The chute channel was superposed on bend (B), which developed later. Furthermore, bend (A) migrated with the expansion and rotation mode, deviating from the meandering belt axis upstream and creating a chute channel with the translation mode at an earlier stage. Lastly, bend (B) was characterised by lower curvature with the expansion and rotation mode upstream (Fig. 10c-B). 


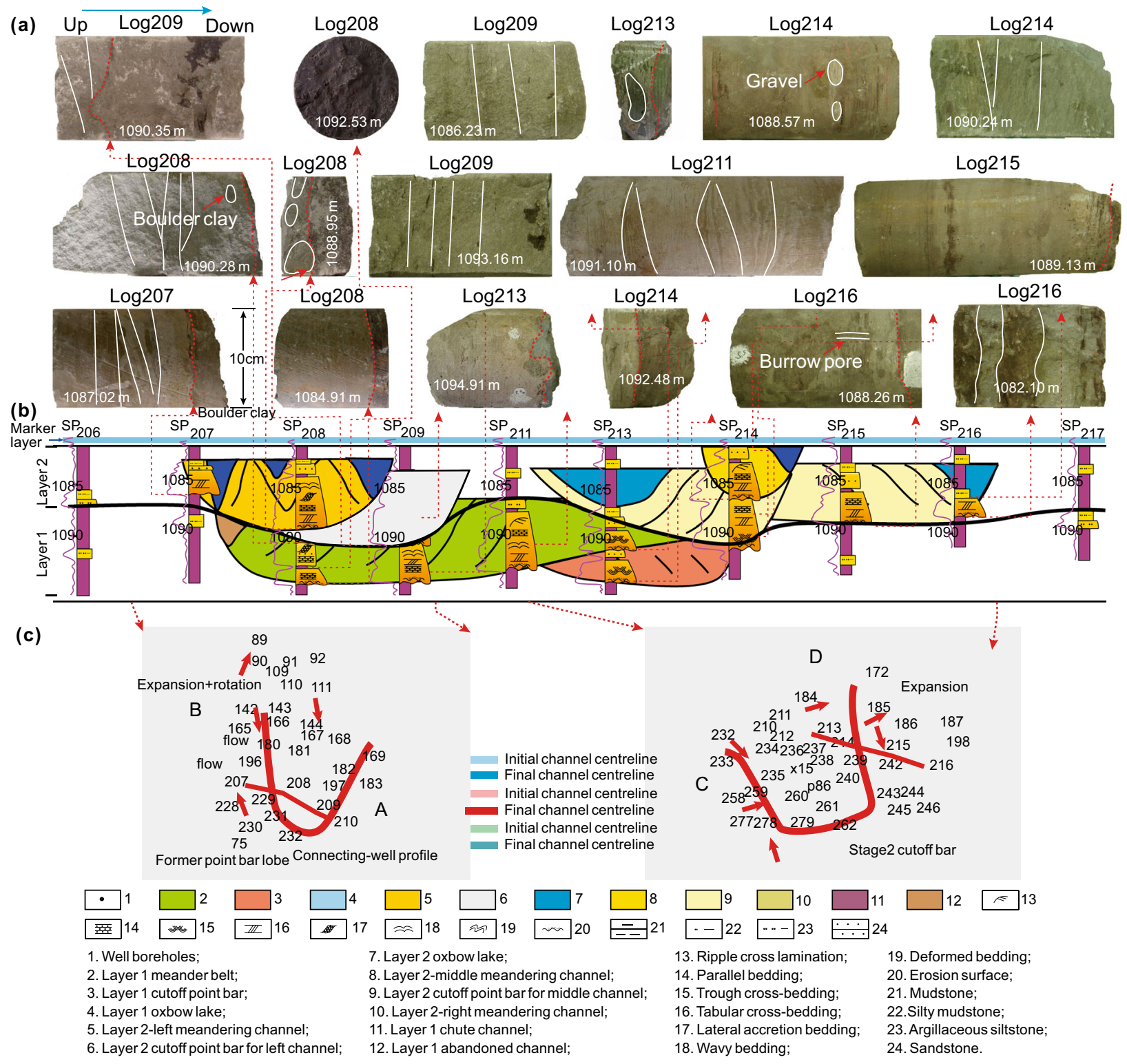

Fig. 9 Profile 3: profile map of comprehensive analysis including evolution model of meandering belt based on multiple-well data collected from the Daqing Oil Field. The profile parallels the

\subsection{Reconstruction of meandering paleo belt architecture}

Based on the detailed results and analysis shown in Fig. 11, the upper layer of the meandering belt was reconstructed with overlapping fine-grained sediments, leading to the preservation of Layer 2. In contrast, the preservation of Layer 1 was inferior because it was destroyed by a latestage meandering channel with powerful undercutting behaviour. The complex meandering belt revealed that the ancient meandering channel easily changed its course, creating a chute channel and cut-off bends. Additionally, a large number of factors affect the formation and evolution transverse axis of the meandering belt, with exaggerated vertical scale: a core data, b lithological interpretation, and c planform interpretation

of the meandering belt by influencing various variables. These factors include climate, sediment load, resistance of banks, and bed to movement by flowing water. Among these variables, the high-frequency cut-off is one of the predominant controlling factors in the formation of the complex meandering belt.

Figure 11 shows an approach to the reconstruction of the ancient meandering belt by combining preliminary results of ancient and current flow analyses. The single meandering belt (blue line) was assembled from different profile portions in the final stage, and the entire channel had a downstream north-south direction. However, in general, the ancient flow of the cut-off bend appeared 


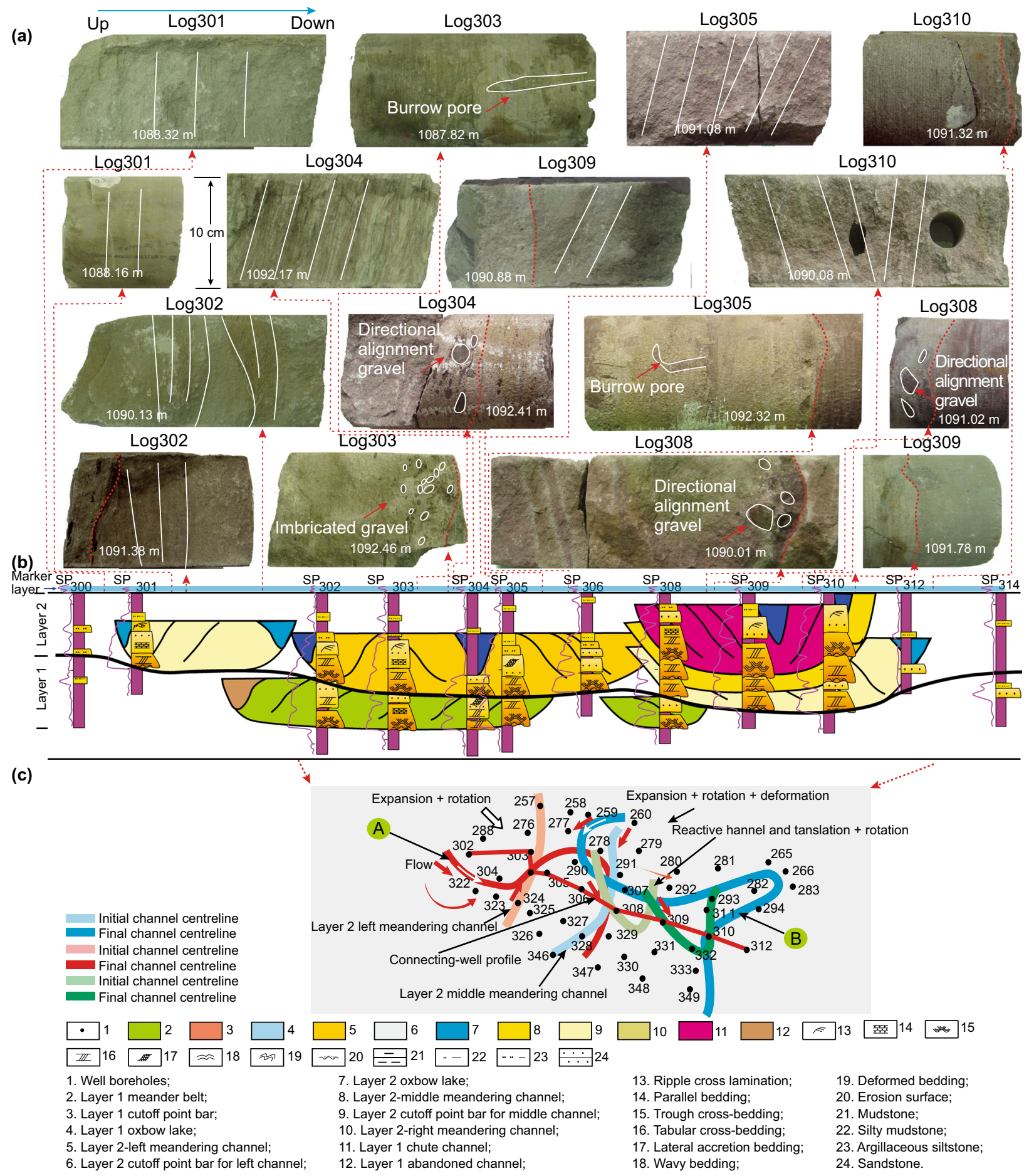

Fig. 10 Profile 4: profile map of comprehensive analysis including evolution model of meandering belt based on multiple-well data from the Daqing Oil Field. The profile parallels the transverse axis of the

discontinuous and frequently developed on the apex of the channel towards the concave bank. The assembly from different profile segments must be reasonable and obey meandering fluid dynamics. To some extent, this assembly meandering belt, with exaggerated vertical scale: a core data, b lithological interpretation, and c planform interpretation

method had a multiplicity of solutions and some uncertainty consequently remains.

Additionally, multi-stage chute channels intensified premeandering sediment complexity, and chute behaviour was prone to inducing abandoned channels. For example, in 


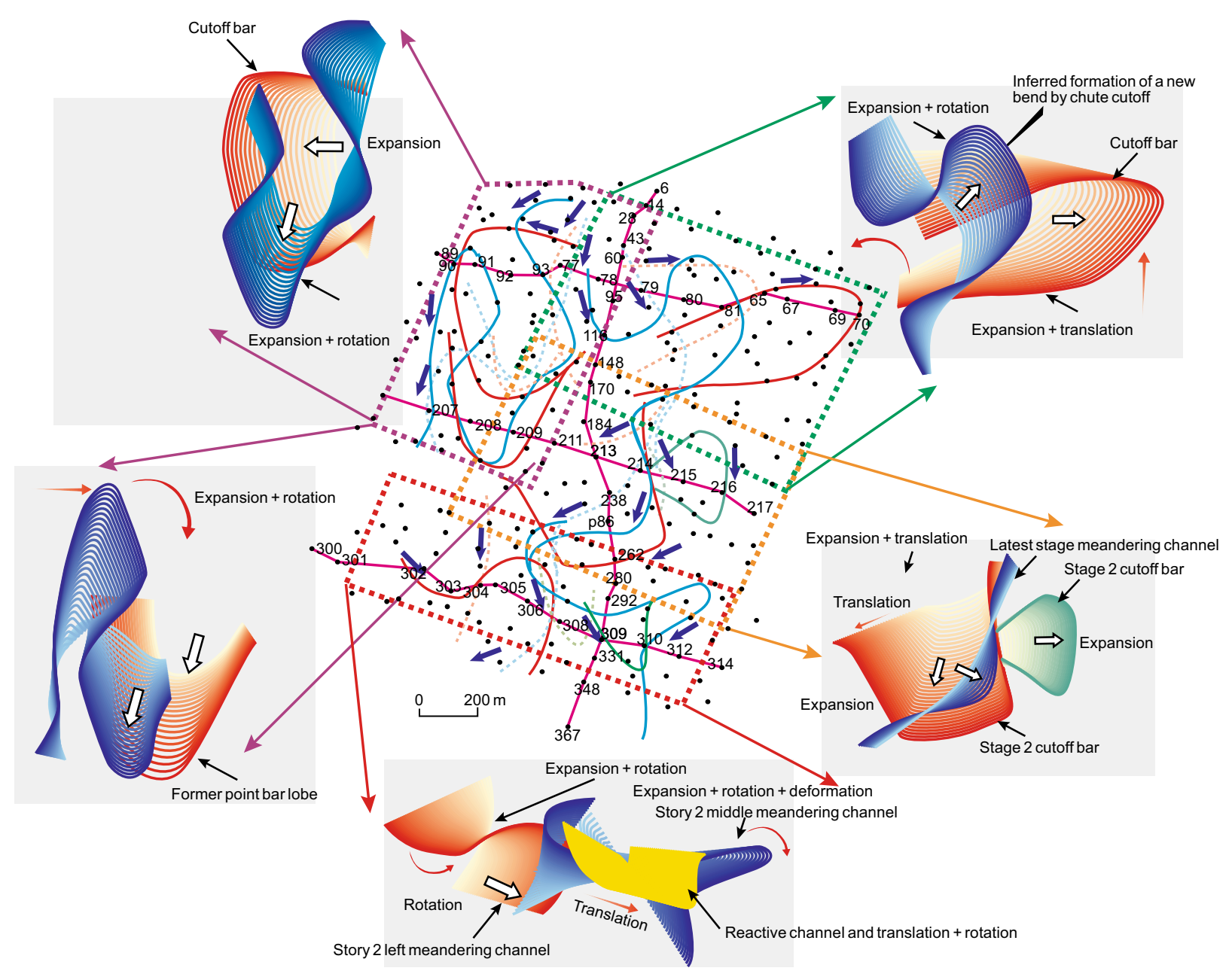

Fig. 11 Ancient planform migration models in the central area of the Songliao Basin

well 308, a small abandoned channel formed after chute behaviour (Fig. 11); the pale green dotted line presents the initial centreline and deep green presents the final channel centreline. After the comprehensive reconstruction of the migration models in each profile, the reconstruction of the complex meandering belt of the study area was ultimately completed as shown in Fig. 12.

\section{Discussion}

A series of 2D, connected well profiles of fluvial deposits demonstrated depositional behaviour and vertical heterogeneity of lithofacies within the meander belt. Although the dense well pattern improved the accuracy of the interpretation, there were still some areas without data, which created uncertainty in the interpretation of the structure. Furthermore, complex channelised reworking increased uncertainty (Eschard et al. 1991; Miall 1994; Miall and Jones 2003; Ielpi and Ghinassi 2014), and the isochronism of chronostratigraphic correction influenced the results.

\subsection{Expansion, translation, rotation, and aggradation}

Meandering bend expansion (Figs. 4a, 12c) increases curvature, flow path length, and sinuosity, and the bend apex migrates away from the meandering belt axis (Jackson 1976; Ghinassi et al. 2013). Meandering bend translation (Figs. 4b, 12b) was characterised by a bend apex parallel to the meandering belt axis without an obvious change in sinuosity aside from the translation and expansion mode. On the other hand, meandering bend rotation (Figs. $4 \mathrm{~d}-\mathrm{f}$, 12a) was characterised by increasing bend asymmetry, an apex shifting away from the meandering belt axis, and a nonlinear migration path. The upstream point bar crawled on or was intercalated with the downstream point bar, which indicated strong expansion of the meandering belt (Fig. 12c). Furthermore, more upstream point bar deposits from the meandering belt axis were well-preserved during 


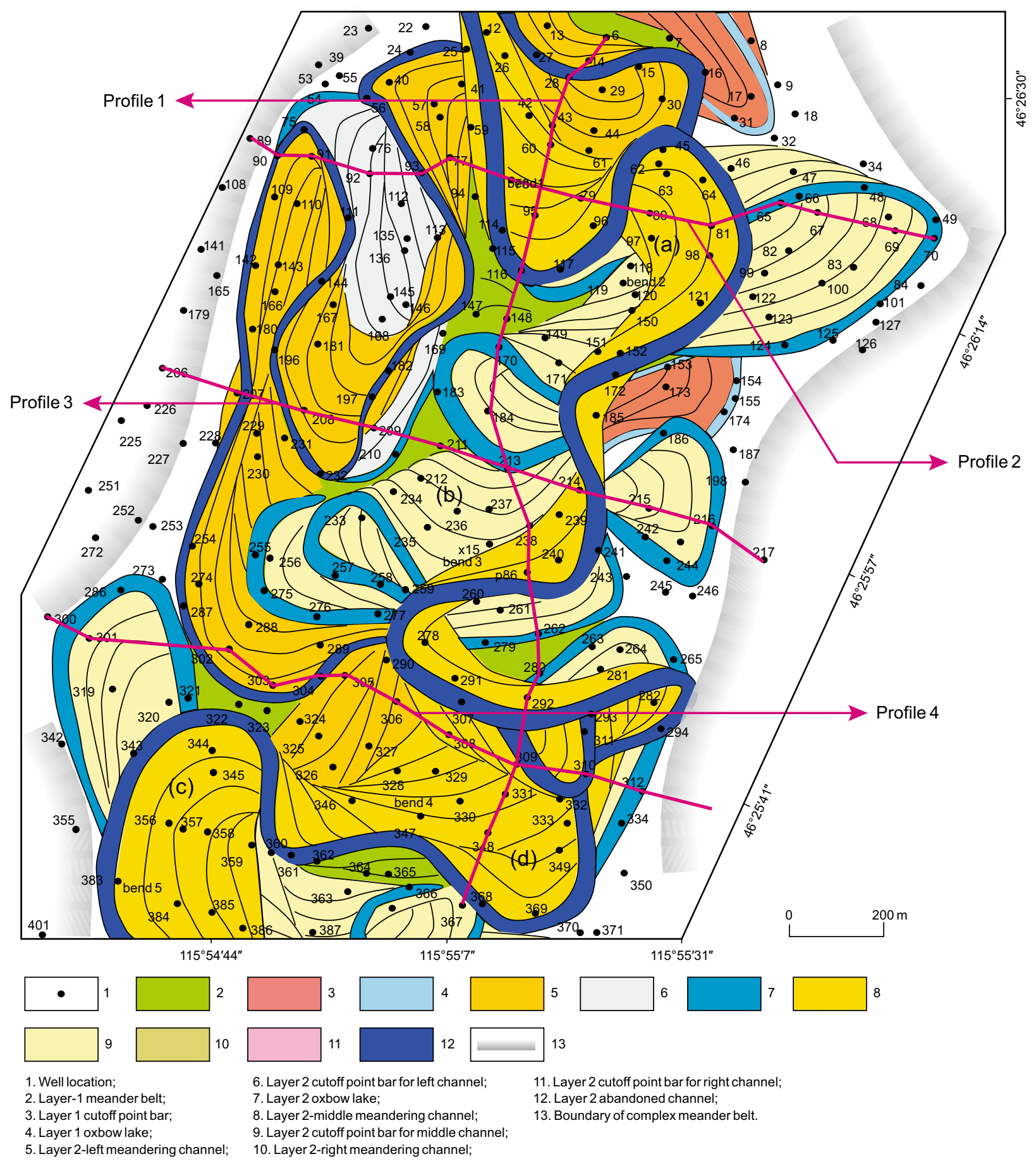

Fig. 12 Reconstruction of the complex meandering belt based on the dense network of well data: a rotation mode, $\mathbf{b}$ translation mode, c expansion mode, and $\mathbf{d}$ expansion mode. Bends 1-5: five bend units

that were used by empirical equations to calculate and compare with the actual scale

continuous expansion (Fig. 12d). During meandering channel transport and deposition, almost all of the upstream bar suffered from partial erosion, leading to thalweg trajectories of the expansion mode migrating downstream. In contrast, those of the translation mode migrated upstream, indicating the paleo-current direction (Fig. 12). The continuous expansion and rotation mode could have led to higher frequency cut-offs because the expansion mode tended to form cut-offs. Moreover, the rotation mode was more prone to form chute channels, which may form a branch channel within a certain period of time. 
Channel aggradation was a more important depositional pattern, and its rate was derived from the direction of thalweg trajectory migration. The denser and steeper the trajectory was, the higher the rate of aggradation became, and the easier it was for the meandering belt to form. In general, a high rate of aggradation indicates that the back bar is prone to roll on, even erasing the front bar, thereby making it difficult for chute channels or cut-offs to form. A higher aggradation rate is closely related to strong hydrodynamic conditions. Conversely, a lower aggradation rate with gentle or straight thalweg trajectories indicates that erosion occurs with a higher frequency. In addition, high aggradation rates are prone to form accretion bedding, whereas lower aggradation rates form lateral bedding.

\subsection{Cause and control factors of meandering channel formation}

The capacity for sediment transportation and bank material composition are important factors that influence the river planform. Planform formation is also related to its own adjustments to achieve sediment transport equilibrium (Qian 1985), and consequently, sinuosity gradually increases. However, this equilibrium is relative; throughout the evolution history of a meandering channel, it is continually adjusting before eventually stabilising (Gutierrez and Abad 2014). In addition, the meandering channel can be divided into high and low sinuosity at the critical value of 1.7, which is derived from a large number of meandering channels (Schumm and Lichty 1963; Leeder 1973).

Furthermore, sediments of high and low sinuosity meandering channels are different from each other (Ghinassi et al. 2016). Under relative strong hydrodynamic conditions, the coarse sediments carried by the channel generally exhibit weak lateral accretion, while those fine sediments exhibit strong lateral accretion.

The identification of a single bend from a complex compound meandering belt contains uncertainty due to the complexity of generations among the bends, and therefore estimation and reconstruction of a subsurface meandering belt are difficult. For extremely complex cases, the meandering belt is unrecoverable. Hence, this is a huge systematic project that can be improved continuously by increasing well density.

\subsection{Comparison of results from empirical equations and actual reconstruction}

The real channel depth may be influenced by a great variety of factors, such as compaction, erosion, and interactions between different channels of different stages. However, the study strata of Layer 2 are in the late evolutionary stage at the end of the fluvial deposition period in the Yaojia Formation, thus attention can be paid predominately to the interpretation of compaction. The meandering belt studied here was characterised by channels with a mean depth of $5 \mathrm{~m}$ from the channel interpretations of the profiles above. This should be considered a minimum thickness to account for post-depositional compaction. Furthermore, the original bankfull depth (Gibling 2006) should be considered for recovery. Sediment volume is gradually reduced through loss of interparticle porosity (Feng et al. 2010), and, therefore, when results based on research on modern channels are used to estimate quantitative parameters, the ancient sedimentary thickness should be restored to pre-surface levels through a decompaction correction. Thus, a quantitative correction between modern and ancient sediments was established to acquire the geometric and hydraulic parameters using an empirical equation based on modern sediments. Magara (1973) presented an equation for burial depth and porosity based on clay analysis:

$\varphi=\varphi_{0} \mathrm{e}^{-C Z}$

where $\varphi_{0}$ is the initial surface porosity, $\varphi$ is the buried porosity, and $C$ is the compaction coefficient $\left(\mathrm{m}^{-1}\right)$. Hegarty et al. (1988) generalised this equation for application to all types of sandstone and mudstone and obtained another compaction coefficient $C$. Therefore, the thickness (sandstone and mudstone)-burial depth equation is as follows:

$\int\left(0 \rightarrow H_{0}\right)\left(1-\varphi_{0} \mathrm{e}^{-C Z}\right) \mathrm{d} z=\int(0 \rightarrow z+H)\left(1-\varphi_{0} \mathrm{e}^{-C Z}\right) \mathrm{d} z$

where $\varphi_{0}(\%)$ is the initial surface porosity, $C$ is the compaction coefficient, $H_{0}(\mathrm{~m})$ is the initial surface thickness, $z(\mathrm{~m})$ is the burial depth, and $H(\mathrm{~m})$ is the burial

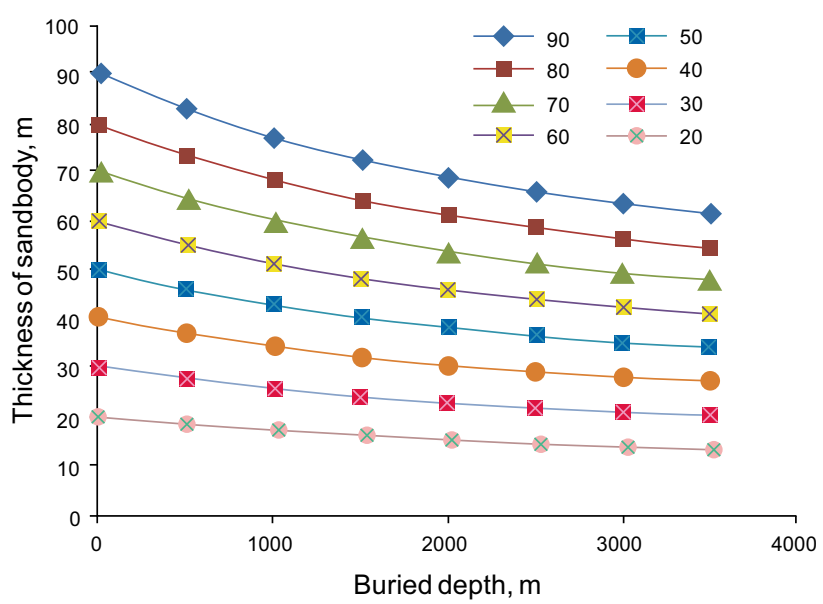

Fig. 13 Sandstone thickness variation with increasing burial depth, sandstone materials from Feng et al. (2010) 
Table 3 Sandstone compaction rates at different burial depths

\begin{tabular}{llllllll}
\hline Burial depth $z, \mathrm{~m}$ & 0 & 500 & 1000 & 1500 & 2000 & 2500 & 3000 \\
$\begin{array}{l}\text { Compaction rate } \\
n\end{array}$ & 1 & 1.08 & 1.16 & 1.23 & 1.32 & 1.35 & 1.40 \\
\hline
\end{tabular}

Table 4 Empirical equations for estimating quantitative parameters of meandering channels

\begin{tabular}{|c|c|c|c|c|c|}
\hline \multirow[t]{2}{*}{ Reference number } & \multirow[t]{2}{*}{ Equation } & \multirow[t]{2}{*}{ Unit } & \multicolumn{2}{|c|}{ Standard deviation of residuals, $\%$} & \multirow[t]{2}{*}{ Correlation coefficient } \\
\hline & & & + & - & \\
\hline 1 & $W_{\mathrm{c}}=6.8 D^{1.54}$ & $\mathrm{~m}$ & I & / & / \\
\hline 2 & $W_{\mathrm{m}}=4.3 W_{\mathrm{c}}^{1.12}$ & $\mathrm{~m}$ & 74 & 42 & 0.96 \\
\hline 3 & $L_{\mathrm{b}}=5.1 W_{\mathrm{c}}^{1.12}$ & $\mathrm{~m}$ & 65 & 39 & 0.97 \\
\hline 4 & $L_{\mathrm{m}}=7.5 W_{\mathrm{c}}^{1.12}$ & $\mathrm{~m}$ & 65 & 39 & 0.96 \\
\hline 5 & $R_{\mathrm{b}}=1.5 W_{\mathrm{c}}^{1.12}$ & $\mathrm{~m}$ & 55 & 35 & 0.97 \\
\hline 6 & $S=14 \mathrm{e}^{0.42 D-0.31}$ & / & I & / & / \\
\hline 7 & $Q=0.004 \mathrm{e}^{1.61 \ln L_{\mathrm{m}}}$ & $\mathrm{m}^{3} / \mathrm{s}$ & / & / & / \\
\hline
\end{tabular}

thickness. The initial porosity of sandstone is $45 \%$ and its empirical $C$ is 0.00025 . Thickness after post-depositional compaction was calculated using these initial thickness data before compaction $(20 \mathrm{~m}, 30 \mathrm{~m}, 40 \mathrm{~m}, \ldots, 90 \mathrm{~m})$, and the results are shown in Fig. 13. Based on the abovementioned empirical relationship, compaction rates are summarised in Table 3. Using the rates in Table 3 , the 5-m-thick channel sandstone from a depth of $1100 \mathrm{~m}$ was restored to its original thickness of approximately $5.8 \mathrm{~m}$.

The equations used in this study are presented in Table 4. Equation 1 is from Leeder (1973), Eqs. 2-5 are from Williams (1986) (Table 2, Eq. 30-33), Eq. 6 was compiled by the authors, but based on Leeder (1973) and Williams (1986) (Table 2, Eq. 40), and Eq. 7 is from Carlston (1965), albeit slightly modified. $D$ is the mean bankfull depth, $R_{\mathrm{b}}$ is the channel bend radius of curvature, $L_{\mathrm{m}}$ is the meander wavelength, $S$ is channel sinuosity, $L_{\mathrm{b}}$ is the along channel bend length, $W_{\mathrm{c}}$ is the mean bankfull channel width, $Q$ is the annual average discharge rate, and $W_{\mathrm{m}}$ is the meandering belt width.

Using the above-mentioned restored paleo-channel thickness values, other relevant parameters could be estimated by using the empirical equations compiled by Williams (1986) and based on instances of modern sediments with sinuosities of $\geq 1.2$, combined with the hydrodynamic equation of Carlston (1965) (Table 4).

The results showed that the reconstruction parameters were in accordance with the estimates from the seven empirical equation in Table 4, except for bend 2, which was slightly larger (Table 5). In comparison, the larger geometric parameter values from the equations (Table 4, Eqs. 1-7) indicated that these statistical estimates were highly approximate or were due to an equation derived from the uncompacted modern sediment samples, and the thickness therefore seems exaggerated. Bend 2 (Fig. 10) was characterised by a translation migration mode (Fig. 4b), whereas bend 3 experienced expansion (Fig. 4a). Contrasting with the results shown in Table 5 , bend 2 showed a stronger hydrodynamic force, and this kind of bend is prone to downstream migration with an erosional upstream bar and overlapped downstream bar under strong hydrodynamic conditions.

\section{Conclusions}

1. An investigation based on Google Earth images (Fig. 4) showed that meandering channel migration patterns are characterised by expansion, translation, rotation, expansion and translation, expansion and downstream rotation, constriction and downstream rotation, and expansion and countercurrent rotation modes, but the meandering channel migration patterns were mainly composed of the above-mentioned migration models under natural conditions. The expansion mode was prone to cut-offs because of continuously increasing sinuosity when the path length reached a certain critical value. The neck of the bend was cut and formed an abandoned channel. Furthermore, the rotation pattern more easily formed chute channels because of continuously increasing sinuosity combined with strong hydrodynamic forces and increased the probability of a crevasse and chute channel.

2. From estimations made using empirical equations, the ancient mean bankfull width $\left(W_{\mathrm{c}}\right)$ was approximately 


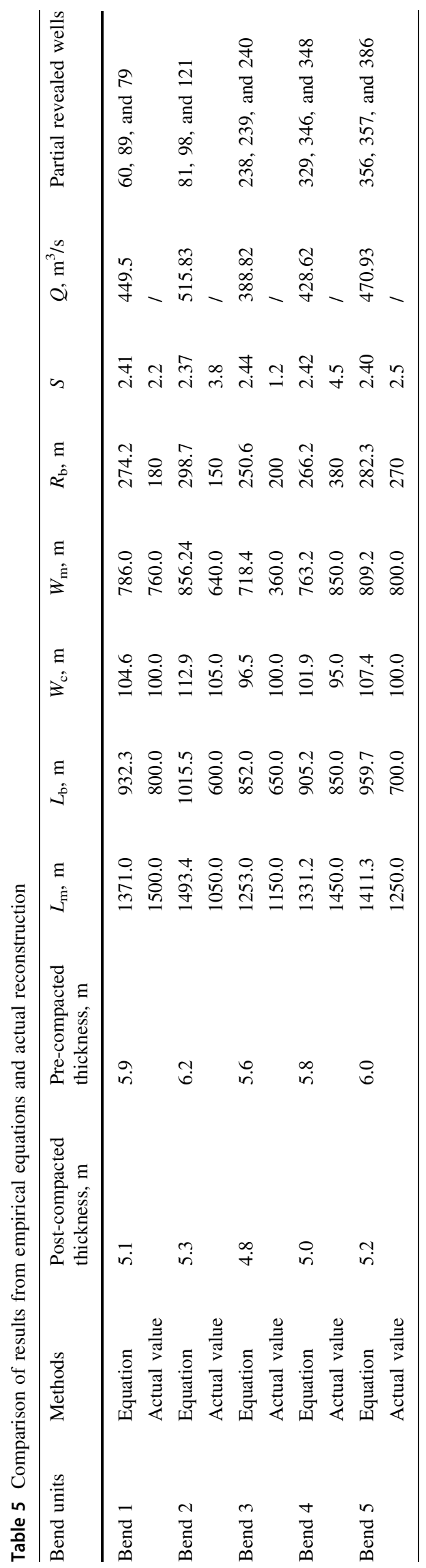

$100 \mathrm{~m}$, the single meandering belt mean width was approximately $800 \mathrm{~m}$, the mean channel bend radius of curvature was approximately $250 \mathrm{~m}$, the mean along channel bend length was approximately $700 \mathrm{~m}$, the mean meander wavelength was approximately $1300 \mathrm{~m}$, the channel average sinuosity was approximately almost 3.0 ( $S>1.7$ was high sinuosity), and the annual mean discharge rate was approximately $450 \mathrm{~m}^{3} / \mathrm{s}$. For multi-layer fluvial successions, the lower portion was more easily eroded, and therefore it was difficult to completely preserve the bottom meandering belt. On a geological timescale, the meandering channel was more prone to reworking. During meandering channel evolution, the direction of diverging thalweg trajectories indicated that the upstream bar was subjected to powerful erosion, whereas the downstream bar experienced expansion, translation, or rotation.

3. The results from seven empirical equations and the actual reconstruction agreed, indicating that ancient sedimentary thickness should be restored to original surface levels through decompaction correction to acquire the real geometric parameters of the meandering channel. Otherwise, the results would be smaller than the actual values.

4. The structure of ancient meandering channels is exceedingly complex and, in terms of geological time, tends to have continuous cut-offs that contribute to meandering belt formation.

Acknowledgements This research was also supported by the National Natural Science Foundation of China (No. 41372125) and National Science and Technology Major Project (No. 2016ZX05063002-006). We thank also Accdon for linguistic assistance during the preparation of this manuscript. We deeply appreciate Associate Editor Dr. Chenglin Gong and the two anonymous reviewers for their insightful comments and suggestions.

Open Access This article is distributed under the terms of the Creative Commons Attribution 4.0 International License (http://creative commons.org/licenses/by/4.0/), which permits unrestricted use, distribution, and reproduction in any medium, provided you give appropriate credit to the original author(s) and the source, provide a link to the Creative Commons license, and indicate if changes were made.

\section{References}

Abad JD, Frias CE, Buscaglia GC, et al. Modulation of the flow structure by progressive bedforms in the Kinoshita meandering channel. Earth Surf Proc Landf. 2013;38(13):1612-22. https:// doi.org/10.1002/esp.3460.

Abad JD, Garcia MH. RVR Meander: a toolbox for re-meandering of channelized streams. Comput Geosci. 2006;32(1):92-101. https://doi.org/10.1016/j.cageo.2005.05.006. 
Abad JD, Garcia MH. Experiments in a high-amplitude Kinoshita meandering channel: 2. Implications of bend orientation on bed morphodynamics. Water Resour Res. 2009;45(2):W02402. https://doi.org/10.1029/2008wr007016.

Brice JC. Evolution of meander loops. Geol Soc Am Bull. 1974;85(4):581-6. https://doi.org/10.1130/00167606(1974)85\%3c581:EOML\%3e2.0.CO;2.

Bridge JS, Jalfin GA, Georgieff SM. Geometry, lithofacies, and spatial distribution of Cretaceous fluvial sandstone bodies, San Jorge Basin, Argentina: outcrop analog for the hydrocarbonbearing Chubut Group. J Sediment Res. 2000;70(2):341-59. https://doi.org/10.1306/2DC40915-0E47-11D7$8643000102 \mathrm{C} 1865 \mathrm{D}$.

Carlston CW. The relation of free meander geometry to stream discharge and its geomorphic implications. Am J Sci. 1965;263(10):864-85. https://doi.org/10.2475/ajs.263.10.864.

Chen D, Duan JD. Simulating sine-generated meandering channel evolution with an analytical model. J Hydraul Res. 2006;44(3):363-73. https://doi.org/10.1080/00221686.2006. 9521688

Chen L, Lin Z, Yin T, et al. Meandering process and migration architecture: based on the Nowitna River. Earth Sci Res. 2017;6(2):76-90. https://doi.org/10.5539/esr.v6n2p76.

Collinson JD, Collinson D, Thompson DB. Sedimentary structures. Toledo, OH: HarperCollins; 1982.

Cuevas Martínez JL, Cabrera Pérez L, Marcuello A, et al. Exhumed channel sandstone networks within fluvial fan deposits from the Oligo-Miocene Caspe Formation, South-east Ebro Basin (Northeast Spain). Sedimentology. 2010;57(1):162-89. https://doi.org/ 10.1111/j.1365-3091.2009.01096.x.

Donselaar ME, Overeem I. Connectivity of fluvial point-bar deposits: an example from the Miocene Huesca fluvial fan, Ebro Basin, Spain. AAPG Bull. 2008;92(9):1109-29. https://doi.org/10.1306/ 04180807079.

Du X, Xie X, Lu Y, et al. Distribution of continental red paleosols and their forming mechanisms in the Late Cretaceous Yaojia Formation of the Songliao Basin, NE China. Cretac Res. 2011;32(2):244-57. https://doi.org/10.1016/j.cretres.2010.12. 010.

Engel FL, Rhoads BL. Three-dimensional flow structure and patterns of bed shear stress in an evolving compound meander bend. Earth Surf Proc Landf. 2016;41(9):1211-26. https://doi.org/10. 1002/esp.3895.

Eschard R, Ravenne C, Houel P, et al. Three-dimensional reservoir architecture of a valley-fill sequence and a deltaic aggradational sequence: influences of minor relative sea-level variations (Scalby Formation, England). In: Miall AD, Tyler A, editors. The three-dimensional facies architecture of terrigenous clastic sediments and its implications for hydrocarbon discovery and recovery. SEPM. Concepts in sedimentology and paleontology, vol 3, p. 133-47; 1991. https://doi.org/10.2110/csp.91.03.

Feng Z, Jia C, Xie X, et al. Tectonostratigraphic units and stratigraphic sequences of the nonmarine Songliao Basin, northeast China. Basin Res. 2010;22(1):79-95. https://doi.org/ 10.1111/j.1365-2117.2009.00445.x.

Frascati A, Lanzoni S. Morphodynamic regime and long-term evolution of meandering rivers. J Geophys Res Earth Surf. 2009. https://doi.org/10.1029/2008jf001101.

Ghinassi M, Billi P, Libsekal Y, et al. Inferring fluvial morphodynamics and overbank flow control from 3D outcrop sections of a Pleistocene point bar, Dandiero Basin, Eritrea. J Sediment Res. 2013;83(12):1066-84. https://doi.org/10.2110/jsr.2013.80.

Ghinassi M, Ielpi A, Aldinucci M, et al. Downstream-migrating fluvial point bars in the rock record. Sediment Geol. 2016;334:66-96. https://doi.org/10.1016/j.sedgeo.2016.01.005.
Ghinassi M, Nemec W, Aldinucci M, et al. Plan-form evolution of ancient meandering rivers reconstructed from longitudinal outcrop sections. Sedimentology. 2014;61(4):952-77. https:// doi.org/10.1111/sed.12081.

Gibling MR. Width and thickness of fluvial channel bodies and valley fills in the geological record: a literature compilation and classification. J Sediment Res. 2006;76(5):731-70. https://doi. org/10.2110/jsr.2006.060.

Güneralp I, Abad JD, Zolezzi G, et al. Advances and challenges in meandering channels research. Geomorphology. 2012;163-164:1-9. https://doi.org/10.1016/j.geomorph.2012.04. 011.

Güneralp İ, Rhoads BL. Influence of floodplain erosional heterogeneity on planform complexity of meandering rivers. Geophys Res Lett. 2011;38(14):L14401. https://doi.org/10.1029/ 2011 GL048134.

Gutierrez RR, Abad JD. On the analysis of the medium term planform dynamics of meandering rivers. Water Resour Res. 2014;50(5):3714-33. https://doi.org/10.1002/2012WR013358.

Harms JC, Southard JB, et al. Depositional environments as interpreted from primary sedimentary structures and stratification sequences. SEPM Short Course. 1975;2:5-43.

Hegarty KA, Weissel JK, Mutter JC. Subsidence history of Australia's southern margin: constraints on basin models. AAPG Bull. 1988;72(5):615-33.

Hickin EJ. The development of meanders in natural river-channels. Am J Sci. 1974;274(4):414-42. https://doi.org/10.2475/ajs.274. 4.414.

Hooke J. Changes in river meanders: a review of techniques and results of analyses. Prog Phys Geog. 1984;8(4):473-508. https:// doi.org/10.1177/030913338400800401.

Hooke J. River meander behaviour and instability: a framework for analysis. Trans Inst Br Geogr. 2003;28(2):238-53. https://doi. org/10.1111/1475-5661.00089.

Hubbard SM, Smith DG, Nielsen H, et al. Seismic geomorphology and sedimentology of a tidally influenced river deposit, Lower Cretaceous Athabasca oil sands, Alberta, Canada. AAPG Bull. 2011;95(7):1123-45. https://doi.org/10.1306/12131010111.

Ielpi A, Ghinassi M. Planform architecture, stratigraphic signature and morphodynamics of an exhumed Jurassic meander plain (Scalby Formation, Yorkshire, UK). Sedimentology. 2014;61(7):1923-60. https://doi.org/10.1111/sed.12122.

Jackson RG. Depositional model of point bars in the lower Wabash River. J Sediment Res. 1976;46(3):579-94. https://doi.org/10. 1306/212f6ff5-2b24-11d7-8648000102c1865d.

Johannesson H, Parker G. Linear theory of river meanders. In: Ikeda S, Parker G, editors. River meandering. New York, NY: Wiley; 1989. p. 181-213.

Kasvi E. Fluvio-morphological processes of meander bends-combining conventional field measurements, close-range remote sensing and computational modelling. Turku: University of Turku; 2015.

Konsoer KM, Rhoads BL, Langendoen EJ, et al. Spatial variability in bank resistance to erosion on a large meandering, mixed bedrock-alluvial river. Geomorphology. 2016;252:80-97. https://doi.org/10.1016/j.geomorph.2015.08.002.

Langendoen EJ, Mendoza A, Abad JD, et al. Improved numerical modeling of morphodynamics of rivers with steep banks. Adv Water Resour. 2016;93(Part A):4-14. https://doi.org/10.1016/j. advwatres.2015.04.002.

Leeder MR. Fluviatile fining-upwards cycles and the magnitude of palaeochannels. Geol Mag. 1973;110(03):265-76. https://doi. org/10.1017/S0016756800036098.

Leeder MR, Nami M. Sedimentary models for the non-marine Scalby Formation (Middle Jurassic) and evidence for late Bajocian/ Bathonian uplift of the Yorkshire Basin. Proc Yorks Geol Soc. 1979;42:461-82. https://doi.org/10.1144/pygs.42.3.461. 
Lin Z, Shan J, Chen L. Geomorphology processes of channel planform migration on meandering rivers. Acta Geogr Sin (Engl Ed). 2017;91:134-5. https://doi.org/10.1111/1755-6724.13223.

Lin Z, Shan J, Chen L. Geomorphology processes of channel planform migration on modern meandering rivers. Acta Sedimentol Sin. 2018;36(6):427-45. https://doi.org/10.14027/j.issn. 1000-0550.2018.045 (in Chinese).

Magara K. Compaction and fluid migration in Cretaceous shales of western Canada. Paper 72-18, vol 111, issue 4. Ottawa: Geological Survey of Canada; 1973. p. 360. https://doi.org/10. 1017/s0016756800038851.

Mendoza A, Abad JD, Frias CE, et al. Planform dynamics of the Iquitos anabranching structure in the Peruvian Upper Amazon River. Earth Surf Proc Landf. 2016;41(7):961-70. https://doi. org/10.1017/S0016756800038851.

Miall AD. Lithofacies types and vertical profile models in braided river deposits: a summary. In: Miall AD, editor. Fluvial sedimentology, vol. 5. Calgary: Canadian Society of Petroleum Geologists: Memoir; 1977. p. 597-604.

Miall AD. Architectural-element analysis: a new method of facies analysis applied to fluvial deposits. Earth Sci Rev. 1985;22(4):261-308. https://doi.org/10.1016/00128252(85)90001-7.

Miall AD. Reconstructing fluvial macroform architecture from twodimensional outcrops: examples from the Castlegate Sandstone, Book Cliffs, Utah. J Sediment Res. 1994;64(2):146-58. https:// doi.org/10.1306/D4267F78-2B26-11D7-8648000102C1865D.

Miall AD. Fluvial depositional systems. New York, NY: Springer; 2014.

Miall AD, Jones BG. Fluvial architecture of the Hawkesbury sandstone (Triassic), near Sydney, Australia. J Sediment Res. 2003;73(4):531-45. https://doi.org/10.1306/111502730531.

Motta D, Abad JD, Langendoen EJ, et al. A simplified 2D model for meander migration with physically-based bank evolution. Geomorphology. 2012a;163-164:10-25.

Motta D, Abad JD, Langendoen EJ, et al. The effects of floodplain soil heterogeneity on meander planform shape. Water Resour Res. 2012b;48(9):W09518. https://doi.org/10.1029/ 2011WR01160.

Nami M. An exhumed Jurassic meander belt from Yorkshire, England. Geol Mag. 1976;113(1):47-52. https://doi.org/10. 1017/S0016756800043004.

Neal A. Ground-penetrating radar and its use in sedimentology: principles, problems and progress. Earth Sci Rev. 2004;66(3):261-330. https:// doi.org/10.1016/j.earscirev.2004.01.004.

Perucca E, Camporeale C, Ridolfi L. Significance of the riparian vegetation dynamics on meandering river morphodynamics. Water Resour Res. 2007;43(3):W03430. https://doi.org/10.1029/ 2006WR005234.

Qian N. On the classification and causes of formation of different channel patterns. Acta Geogr Sin. 1985;40(1):1-10. https://doi. org/10.11821/xb198501001 (in Chinese).

Ruiu J, Caumon G, Viseur S. Modeling channel forms and related sedimentary objects using a boundary representation based on non-uniform rational B-splines. Math Geosci. 2016;48(3):259-84. https://doi.org/10.1007/s11004-015-9629-3.

Schrott L, Sass O. Application of field geophysics in geomorphology: advances and limitations exemplified by case studies. Geomorphology. 2008;93(1):55-73. https://doi.org/10.1016/j.geomorph. 2006.12.024.

Schumm SA, Lichty RW. Channel widening and flood-plain construction along Cimarron River in southwestern Kansas. Prof. Paper 352-D. Alexandria, VA: USGS; 1963.

Schwendel AC, Nicholas AP, Aalto RE, et al. Interaction between meander dynamics and floodplain heterogeneity in a large tropical sand-bed river: the Rio Beni, Bolivian Amazon. Earth
Surf Proc Landf. 2015;40(15):2026-40. https://doi.org/10.1002/ esp. 3777.

Seminara G. Meanders. J Fluid Mech. 2006;554:271-97. https://doi. org/10.1017/S0022112006008925.

Seminara G. Fluvial sedimentary patterns. Annu Rev Fluid Mech. 2010;42:43-66. https://doi.org/10.1146/annurev-fluid-121108145612.

Shan JF. Architectural element method for fluvial reservoir. Beijing: Science Press; 2017.

Słowik M. Holocene evolution of meander bends in lowland river valley formed in complex geological conditions (the Obra River, Poland). Geogr Ann A. 2014;96(1):61-81. https://doi.org/10. 1111/geoa.12029.

Słowik M. The influence of meander bend evolution on the formation of multiple cutoffs: findings inferred from floodplain architecture and bend geometry. Earth Surf Proc Landf. 2016;41(5):626-41. https://doi.org/10.1002/esp.3851.

Smith DG, Hubbard SM, Lavigne JR, et al. Stratigraphy of counterpoint bar and eddy-accretion deposits in low energy meander belts of the Peace-Athabasca delta, northeast Alberta, Canada. In: From river to rock record: the preservation of fluvial sediments and their subsequent interpretation, vol 97. SEPM Special Publication; 2011. p. 143-52. https://doi.org/10.2110/ sepmsp.097.143.

Smith DG, Hubbard SM, Leckie DA, et al. Counter point bar deposits: lithofacies and reservoir significance in the meandering modern Peace River and ancient McMurray Formation, Alberta, Canada. Sedimentology. 2009;56(6):1655-69. https://doi.org/10.1111/j. 1365-3091.2009.01050.x.

Sorokin AP, Malyshev YF, Kaplun VB, et al. Evolution and deep structure of the Zeya-Bureya and Songliao sedimentary basins (East Asia). Russ J Pac Geol. 2013;7(2):77-91. https://doi.org/ 10.1134/S1819714013020085.

Tornqvist TE. Holocene alternation of meandering and anastomosing fluvial systems in the Rhine-Meuse delta (central Netherlands) controlled by sea-level rise and subsoil erodibility. J Sediment Res. 1993;63(4):683-93. https://doi.org/10.1306/D4267BB82B26-11D7-8648000102C1865D.

Waksmundzka MI. Sequence stratigraphy of Carboniferous paralic deposits in the Lublin Basin (SE Poland). Acta Geol Pol. 2010;60(4):557-97.

Waksmundzka MI. Braided-river and hyperconcentrated-flow deposits from the Carboniferous of the Lublin Basin (SE Poland) - a sedimentological study of core data. Geologos. 2012;18(3):135-61. https://doi.org/10.2478/v10118-012-0008-y.

Wang C, Feng Z, Zhang L, et al. Cretaceous paleogeography and paleoclimate and the setting of SKI borehole sites in Songliao Basin, northeast China. Palaeogeogr Palaeoclimatol Palaeoecol. 2013;385:17-30. https://doi.org/10.1016/j.palaeo.2012.01.030.

Wang P, Xie X, Mattern F, et al. The Cretaceous Songliao Basin: volcanogenic succession, sedimentary sequence and tectonic evolution, NE China. Acta Geologica Sinica (Engl Ed). 2007;81(6):1002-11. https://doi.org/10.3321/j.issn:1000-9515.2007. 06.014 .

Williams GP. River meanders and channel size. J Hydrol. 1986;88(1-2):147-64. https://doi.org/10.1016/00221694(86)90202-7.

Willis B. Interpretation of bedding geometry within ancient point-bar deposits. In: Marzo M, Puigdefabregas C, editors. Alluvial sedimentation, special publication 17. International Association of Sedimentologists. Hoboken, NJ: Blackwell; 2009. p. 101-14.

Wu S, Yue D, Liu J, et al. Hierarchy modeling of subsurface palaeochannel reservoir architecture. Sci China Ser D. 2008;51(2):126-37. https://doi.org/10.1007/s11430-008-0624-0.

Xue P. An introduction to reservoir models of point bar facies. Beijing: Petroleum Industry Press; 1991. p. 55-63 (in Chinese). 